\title{
Quantification of diesel exhaust gas phase organics by a thermal desorption proton transfer reaction mass spectrometer
}

M. H. Erickson, H. W. Wallace, and B. T. Jobson

Laboratory for Atmospheric Research, Washington State University, Pullman, WA, USA

Received: 14 January 2012 - Accepted: 7 February 2012 - Published: 20 February 2012 Correspondence to: B. T. Jobson (tjobson@wsu.edu)

Published by Copernicus Publications on behalf of the European Geosciences Union.

Quantification of diesel exhaust gas phase organics

M. H. Erickson et al.

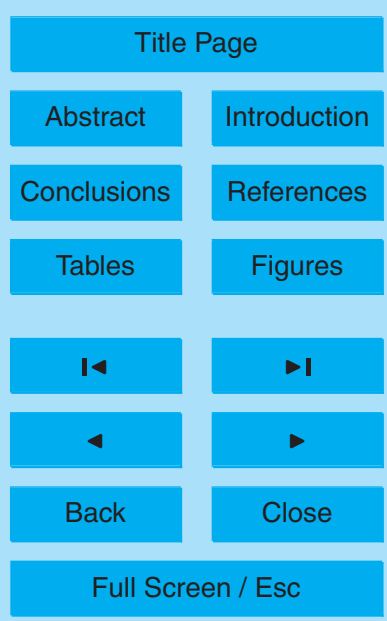

Printer-friendly Version

Interactive Discussion 


\section{Abstract}

A new approach was developed to measure the total abundance of long chain alkanes $\left(\mathrm{C}_{12}\right.$ and above) in urban air using thermal desorption with a proton transfer reaction mass spectrometer (PTR-MS). These species are emitted in diesel exhaust and may

5 be important precursors to secondary organic aerosol production in urban areas. Long chain alkanes undergo dissociative proton transfer reactions forming a series of fragment ions with formula $\mathrm{C}_{n} \mathrm{H}_{2 n+1}$. The yield of the fragment ions is a function of drift conditions. At a drift field strength of 80 Townsends, the most abundant ion fragments from $\mathrm{C}_{10}$ to $\mathrm{C}_{16} n$-alkanes were $\mathrm{m} / z 57,71$ and 85 . The PTR-MS is insensitive to $n$ 10 alkanes less than $\mathrm{C}_{8}$ but displays an increasing sensitivity for larger alkanes. Higher drift field strengths yield greater normalized sensitivity implying that the proton affinity of the long chain $n$-alkanes is less than $\mathrm{H}_{2} \mathrm{O}$. Analysis of diesel fuel shows the mass spectrum was dominated by alkanes $\left(\mathrm{C}_{n} \mathrm{H}_{2 n+1}\right)$, monocyclic aromatics, and an ion group with formula $\mathrm{C}_{n} \mathrm{H}_{2 n-1}(\mathrm{~m} / z 97,111,125,139)$. The PTR-MS was deployed in

15 Sacramento, CA during the Carbonaceous Aerosols and Radiative Effects Study field experiment in June 2010. The ratio of the $\mathrm{m} / \mathrm{z} 97$ to 85 ion intensities in ambient air matched that found in diesel fuel. Total diesel exhaust alkane concentrations calculated from the measured abundance of $\mathrm{m} / \mathrm{z} 85$ ranged from the method detection limit of $\sim 1 \mathrm{\mu g} \mathrm{m}^{-3}$ to $100 \mathrm{\mu g} \mathrm{m}^{-3}$ in several air pollution episodes. The total diesel exhaust alkane concentration determined by this method was on average a factor of 10 greater than the sum of alkylbenzenes associated with spark ignition vehicle exhaust.

\section{Introduction}

The formation of secondary organic aerosol (SOA) in urban areas is not well understood, with models underestimating organic mass loadings (de Gouw et al., 2005; Heald et al., 2005; Johnson et al., 2005; Volkamer et al., 2006). Robinson et al. (2007) proposed that components of organic particulate matter emitted from diesel exhaust

Quantification of diesel exhaust gas phase organics

M. H. Erickson et al.

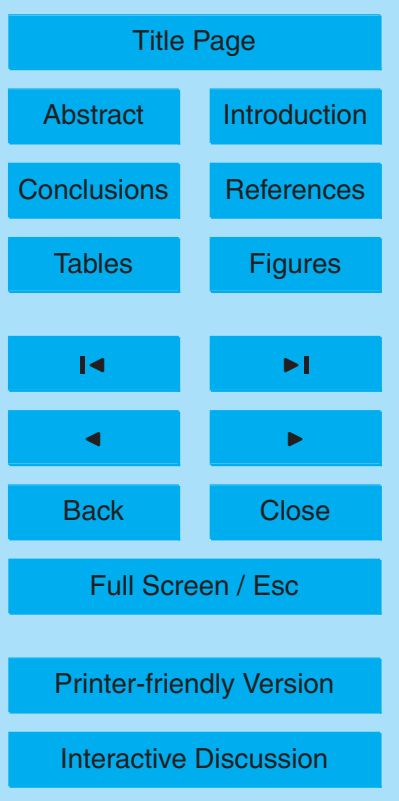


might partition back to the gas phase as the exhaust plume becomes diluted, creating a pool of compounds that act as precursors for SOA. These compounds have been labeled intermediate volatile organic compounds (IVOCs) to distinguish them from more volatile organics compounds (VOCs) emitted from spark ignition engine vehicles burn5 ing gasoline. IVOCs are classified as compounds with a saturation vapor pressure between $1.33 \times 10^{-4}$ and $1.33 \times 10^{-1} \mathrm{hPa}\left(10^{-4}\right.$ and $10^{-1}$ Torr) at $25^{\circ} \mathrm{C}$ (Robinson et al., 2007; Presto et al., 2009). For the $n$-alkanes this vapor pressure range corresponds to dodecane $\left(\mathrm{C}_{12}\right)$ through to octadecane $\left(\mathrm{C}_{18}\right)$. Compounds within this vapor pressure range comprise a large fraction of diesel fuel and exhaust (Han et al., 2008; Schauer 10 et al., 1999; Siegl et al., 1999). Photochemical oxidation of these compounds is likely to produce lower volatility products that partition to the particulate phase forming SOA. Laboratory tests have shown significant formation of SOA from $n$-alkanes (Lim and Ziemann, 2005; Jordan et al., 2008; Samy and Zielinska, 2010) but little is known about SOA yields from other components of diesel fuel such as the larger monoaromatics. Diesel fuel is primarily composed of compounds with carbon numbers ranging between $\mathrm{C}_{12}$ and $\mathrm{C}_{25}$. Analysis of diesel fuel by $\mathrm{GC} \times \mathrm{GC}$ methodology have shown that saturates compose $\sim 70 \%$ and monoaromatics $18 \%$ of the fuel mass (Vendeuvre et al., 2005). Diesel fuel exhaust is composed of unburned fuel, lubricating oil, pyrogenic compounds, and partially oxidized fuel components. The majority of the mass emissions are thought to be saturated compounds such as $n$-alkanes and isoalkanes ranging in carbon number from $\mathrm{C}_{12}$ to $\mathrm{C}_{25}$.

Little appears to be known about the overall abundance of IVOC species in urban environments. Due to their low concentration, low volatility, and the very large number of compounds that comprise diesel exhaust, it is difficult to speciate and quantify these species using gas chromatography sampling and analysis methods. Zielinska et al. (1996) and Lai et al. (2004) reported a relatively wide range of VOCs and IVOC compounds and are useful to assess their relative abundances. Lai et al. (2004) measured $n$-alkanes up to pentadecane in Kaohsiung, Taiwan. Average concentrations for the entire duration of measurement of the individual $C_{8}$ to $C_{15} n$-alkane species ranged from

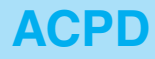

$12,5389-5423,2012$

Quantification of diesel exhaust gas phase organics

M. H. Erickson et al.

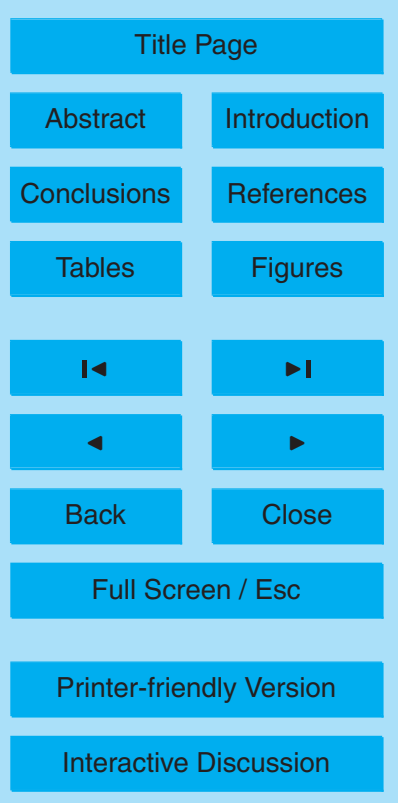


0.37 to $2.72 \mu \mathrm{g} \mathrm{m}^{-3}$ with the total sum of these alkanes reaching up to $16.14 \mu \mathrm{g} \mathrm{m}^{-3}$. A tunnel study performed by Zielinska et al. (1996) reported concentrations of individual $\mathrm{C}_{10}$ to $\mathrm{C}_{13} n$-alkanes reaching as high as $148 \mu \mathrm{g} \mathrm{m}^{-3}$. The tunnel had 2 bores. In the bore dominated by diesel engine vehicle traffic $(68 \%)$ the $n$-alkane to toluene ratio was

51.2 , while in the bore dominated by spark ignition engine traffic $(98 \%)$ the $n$-alkane to toluene ratio was about a factor of ten less. The ratio of $n$-alkanes to toluene was 0.30 for the Taiwan study, suggesting a potentially significant contribution of diesel exhaust organic gases to the organic burden in polluted urban air. While $n$-alkanes are among the most abundant individual components of diesel exhaust they represent only a portion of the overall mass emissions of saturated and aromatic compounds. We present a method to improve the quantification of the mass abundance IVOC species in air using a thermal desorption sampler integrated into a proton transfer reaction mass spectrometer (PTR-MS). The sampling approach is to alternate VOC sampling by the PTR-MS with analysis of heavier organics collected on a thermal desorption sampler. In this way the abundance of IVOC compounds can be compared to the abundance of VOC compounds using the same principle of measurement. The PTR-MS identifies organics by molecular weight (MW). With this approach it appears possible to quantify the total abundance of IVOC alkanes as well as monoaromatics in air. The approach was field tested in an urban setting as part of the Carbonaceous Aerosols and Radiative Effects Study (CARES) (Zaveri et al., 2012; Fast et al., 2011) and field results from the PTR-MS are presented.

\section{Experimental}

\subsection{Thermal desorption sampler}

Figure 1 shows a schematic diagram of the thermal desorption system. Due to the 25 low concentrations of IVOCs in the atmosphere, preconcentration is required for detection by the PTR-MS instrument. Conditioned Tenax TA was used as the adsorbent.

Quantification of diesel exhaust gas phase organics

M. H. Erickson et al.

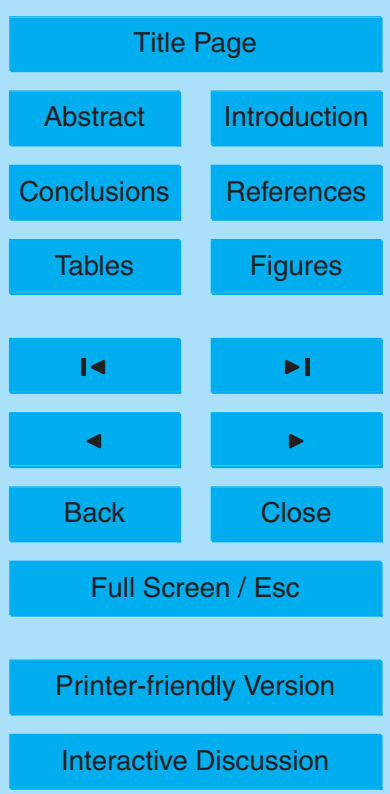


Approximately 0.175 grams of Tenax TA was packed into a $0.172 \mathrm{~cm}\left(0.0675^{\prime \prime}\right)$ ID stainless steel hypodermic tube. The tube was resistively heated with an AC current and temperature controlled using an intelligent phase angle control module (Nu Wave Technologies) controlled by a PID algorithm. Three mass flow controllers were used 5 to regulate the sample, desorption and backflush flows through the adsorbent. The desorption and back flush flows use dry nitrogen gas from a liquid $\mathrm{N}_{2}$ dewar. The absorbent was plumbed into a 2-position six port valve (valco valve). Another mulitposition 4-port valve was used as a stream selector to sample ambient air, zero air, or calibration gas mixture. The system was controlled by a software program (Azeotech 10 DaqFactory) that allowed for automation of the sampling and thermal desorption steps. The thermal desorption system was connected to a custom made sample ring on the PTR-MS drift tube by a $0.0254 \mathrm{~cm}\left(0.01^{\prime \prime}\right)$ ID Restek Sulfinert tube. The sample ring contained another port for the VOC sampling inlet. The thermal desorption trap was positioned directly above the PTR-MS drift tube and electrically isolated from the sam15 ple drift ring. All sampling lines were either heat traced electropolished stainless steel tubing (UHP Cardinal) or silica coated stainless steel tubing (Sulfinert, Restek Corp). The setup allowed for easy switching between the VOC sampling and IVOC desorption sampling without disruption of the drift tube pressure. While the IVOC sample is being collected, the IVOC inlet is closed off ( $\mathrm{S} 1 \mathrm{closed}$ ) and the VOC inlet is open (S2 open) to allow for VOC measurement. The VOC sample is dried by passing the sample through a $-30^{\circ} \mathrm{C}$ cold tube as described in Jobson and McCoskey (2010) and the low abundance of $\mathrm{H}_{2} \mathrm{O}$ vapor in both measurement modes allows for operation of the drift tube at 80 Townsends (Td). The cold trap on the VOC side removes IVOC species through physical adsorption to the cold ice surface.

25 The temperature of the Tenax adsorbent trap was thermostated at one temperature for sampling $\left(35\right.$ or $100^{\circ} \mathrm{C}$ ) and another for thermal desorption $\left(180^{\circ} \mathrm{C}\right)$. By heating the trap during sampling the mass of VOC compounds retained by the Tenax adsorbent could be significantly reduced. At $100^{\circ} \mathrm{C}$ the breakthrough volumes of most VOCs is quite small. The breakthrough volumes at $100^{\circ} \mathrm{C}$ for toluene, dodecane, and

\section{Quantification of diesel exhaust gas phase organics}

M. H. Erickson et al.

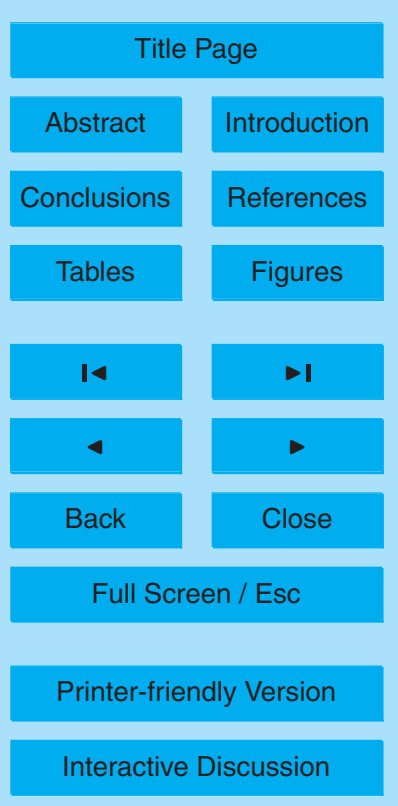


hexadecane are $140 \mathrm{ml}, 2.6 \mathrm{I}$, and $24.5 \mathrm{I}$ respectively. A high trapping temperature thus reduced the degree of VOC ion signal interference in the interpretation of the IVOC mass spectrum. The trap was heated from $100^{\circ} \mathrm{C}$ to $180^{\circ} \mathrm{C}$ in $24 \mathrm{~s}$. The result was a desorption peak, an ion count rate versus time signal, whose area (total counts) was 5 proportional to the mass collected on the adsorbent. Zero air was collected on the trap in the same manner as a sample and peak responses above the zero air signal were determined. No significant contamination or sample carry-over was observed.

\subsection{Calibration using dynamic dilution}

Species with low vapor pressures are typically not very stable as compressed gas 10 standards. For calibrating the PTR-MS response to IVOC species we used a dynamic dilution system based on a low flow syringe pump. A Harvard Apparatus PHD 2000 Infusion syringe injection system was used to deliver small flows of a neat liquid into a dilution flow of air or nitrogen. Multiple syringes could be used so that a mixture of 2 or more compounds could be created by injecting the neat liquids. The needle of a $150.5 \mu \mathrm{l}$ syringe pierced a septum on a stainless steel tee fitting so that the liquid was evaporated under the flow of the diluent gas. The manifold tee where the liquids were injected was temperature controlled between 30 and $60^{\circ} \mathrm{C}$. Downstream of the manifold the tubing was temperature controlled to $80^{\circ} \mathrm{C}$. The PTR-MS sub-sampled from this flow. For the initial tests, the injections were typically performed at $0.5 \mu \mathrm{h}^{-1}$ and di20 luted by a 20 slpm of dry nitrogen resulting in a mixing ratio of approximately 40 ppbv for dodecane. We observed that if the infusion rate is too low then evaporative loss from the needle of the syringe can be greater than the infusion rate. Therefore, infusion rates were kept at values that were high enough as to ensure that the evaporation from the syringe was an insignificant contribution. Using a $0.5 \mu \mathrm{l} \mathrm{Hamilton}$ Gastight syringe, 25 mixing ratios as low as 1 ppbv of dodecane were achieved by diluting a $0.01 \mu \mathrm{h} \mathrm{h}^{-1}$ infusion rate with 20 slpm of nitrogen. The lowest mixing ratios achievable were dependent on the compounds vapor pressure; lower vapor pressures allowing for lower syringe pump infusion rates.
Quantification of diesel exhaust gas phase organics

M. H. Erickson et al.

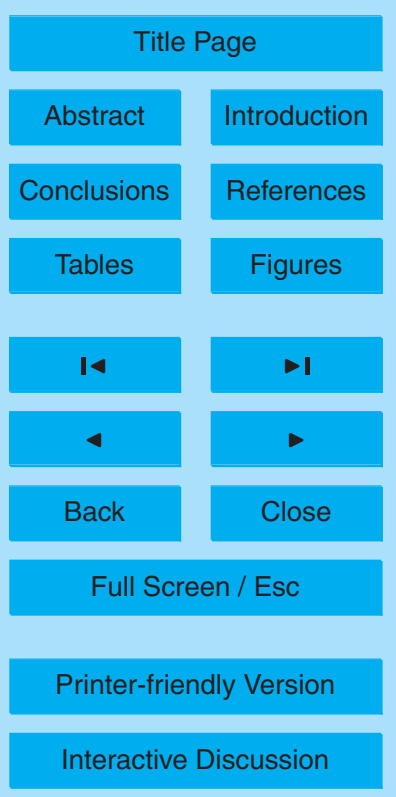


To determine the accuracy of the dynamic dilution system, toluene test mixtures were made ranging from $1 \mathrm{ppbv}$ to $1 \mathrm{ppmv}$ by varying the infusion rate. These mixtures were sampled by the PTR-MS and the measured ion signal converted into a mixing ratio using calibrated response factors determined from a multicomponent VOC compressed 5 gas standard (Scott-Marrin). Using the normalized sensitivities for toluene from the VOC standard (accuracy $\pm 5 \%$ ) the ion signal from the dynamic dilution system could be converted into a measured mixing ratio and compared to the test mixture abundance calculated from the infusion rates and molar flow of the diluent air. This comparison is shown for toluene in Fig. 2. The plot has a slope of $1.04 \pm 0.03$ and an $r^{2}$ value of $10 \quad 0.985$ and gives confidence that the dynamic dilution system could produce accurate test mixtures.

\section{$2.3 n$-alkane response}

The PTR-MS instrument measures organics via a proton transfer reaction with $\mathrm{H}_{3} \mathrm{O}^{+}$:

$\mathrm{H}_{3} \mathrm{O}^{+}+\mathrm{R} \rightarrow \mathrm{H}_{2} \mathrm{O}+\mathrm{RH}^{+}$

15 This reaction will be exothermic if the species $\mathrm{R}$ has a higher proton affinity greater than that of $\mathrm{H}_{2} \mathrm{O}$. Exothermic proton transfer reactions occur near their collision rate limit (Bohme, 1979). The proton affinity of $\mathrm{H}_{2} \mathrm{O}$ is $166.5 \pm 2 \mathrm{kcal} \mathrm{mol}^{-1}$ at $298 \mathrm{~K}$ (Lias et al., 1984) and the proton affinities for larger alkanes approach this value (Hunter and East, 2002). Spanel and Smith (1998) measured $\mathrm{H}_{3} \mathrm{O}^{+}$reactions with alkanes using 20 a selected ion flow tube (SIFT). It was found that larger $n$-alkanes can form an adduct with the hydronium ion:

$\mathrm{H}_{3} \mathrm{O}^{+}+\mathrm{C}_{10} \mathrm{H}_{22}+\mathrm{M} \rightarrow \mathrm{H}^{+}\left(\mathrm{H}_{2} \mathrm{O}\right) \mathrm{C}_{10} \mathrm{H}_{22}+\mathrm{M}$

The study also observed a ligand switching reaction that occurs in the presence of water vapor:

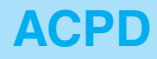

12, 5389-5423, 2012

Quantification of diesel exhaust gas phase organics

M. H. Erickson et al.

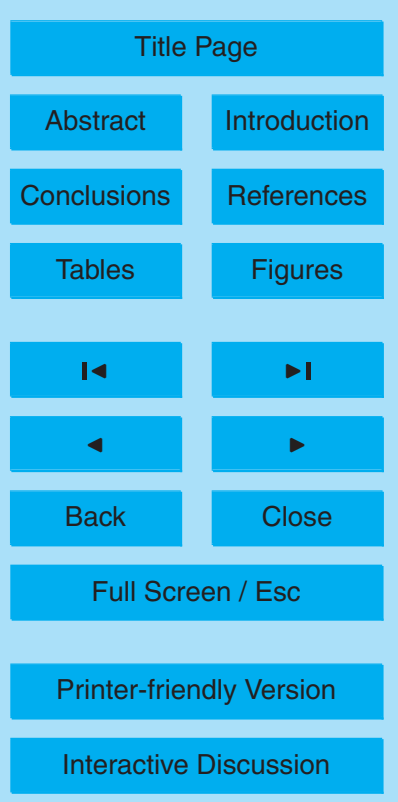


In our studies with the PTR-MS instrument, adducts were observed during measurement of the alkanes at $80 \mathrm{Td}$ but at very low ion signal strength. There was also an increase in signal at $m / z 37$ due to the water cluster $\mathrm{H}^{+}\left(\mathrm{H}_{2} \mathrm{O}\right)_{2}$ resulting from Reaction (R3). In the PTR-MS there are also reactions that occur with $\mathrm{O}_{2}^{+}$ions created in 5 the ion source that confound the interpretation of the PTR-MS mass spectrum as a simple $\mathrm{MW}+1$ mass spectrum. $\mathrm{O}_{2}^{+}$reacts rapidly with alkanes causing extensive fragmentation (Spanel and Smith, 1998). To minimize the influence of $\mathrm{O}_{2}^{+}$, dry $\mathrm{N}_{2}$ was used as the diluent gas in the dynamic dilution system and in thermal desorption from the adsorbent trap. Typically $\mathrm{O}_{2}^{+}$ion count rates were less than $0.1 \%$ of the $\mathrm{H}_{3} \mathrm{O}^{+}$count 10 rate.

The PTR-MS response to $n$-alkanes was determined by preparing known mixtures with the dynamic dilution system in $\mathrm{N}_{2}$. Alkanes undergo dissociative proton transfer reactions in the PTR-MS (Jobson et al., 2005) producing fragmentation patterns similar to electron impact ionization. Figure 3 shows the fragmentation pattern for dodecane 15 as an example of the typical pattern observed for $n$-alkanes. The $C_{8}-C_{16} n$-alkanes produce a significant response and their spectra displayed similar features, yielding a similar relative abundance of fragment ions with the formula $\mathrm{C}_{n} \mathrm{H}_{2 n+1}$ for $n \geq 3$. For heptane and smaller $n$-alkanes there was little response and these species appear to be unreactive with $\mathrm{H}_{3} \mathrm{O}^{+}$. The $n$-alkane fragmentation pattern was a function of the PTR-MS drift tube field strength. At the lower field strengths there was less fragmentation into lighter ions. At $80 \mathrm{Td}$ there was essentially no fragmentation to $\mathrm{m} / \mathrm{z} 41$ and 43 while at $120 \mathrm{Td}$ these were two of the most abundant ion fragments.

The benefit of operating at lower Td is that the $n$-alkane ion signal occurs at larger ion masses allowing for better distinction between IVOC and VOC species. Many VOC 25 species are known to undergo dissociative proton transfer reactions in the PTR-MS and the ions $\mathrm{m} / \mathrm{z} 41,43$ and 57 are common fragment ions from a wide range of species and are typically the most abundant ion signals in PTR-MS analysis of urban air. Table 1 shows the fraction of total ion signal that occurs for each fragment ion for $\mathrm{C}_{8}-\mathrm{C}_{16} n$-alkanes at $80 \mathrm{Td}$. Most of the ion signal is at $\mathrm{m} / \mathrm{z} 57,71$, and 85 . There

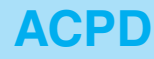

$12,5389-5423,2012$

Quantification of diesel exhaust gas phase organics

M. H. Erickson et al.

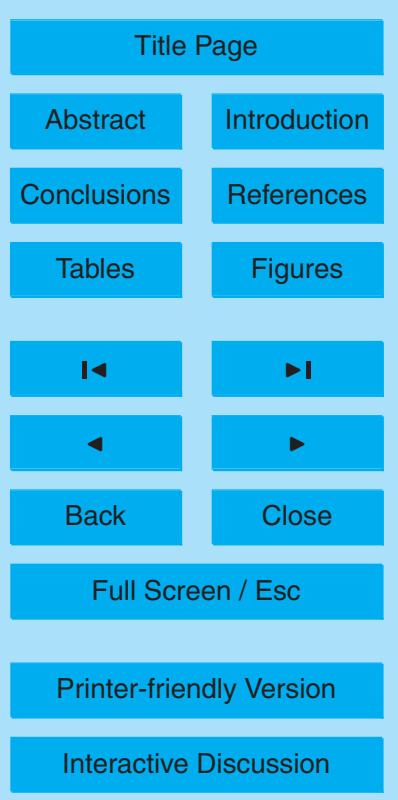


would be significant interference from VOC compounds for ions at $\mathrm{m} / \mathrm{z} 57$ (butenes) and $m / z 71$ (pentenes, methacrolien, methyl vinyl ketone) and to use these ions to monitor for alkanes will require sampling discrimination to prevent VOC collection on the Tenax trap. The ions $m / z 85,99,113$, and 127 may be more unique tracers of long 5 chain alkane abundance in the atmosphere.

The PTR-MS instrument's sensitivity to alkanes was determined by preparing known $n$-alkane and toluene mixtures using the dynamic dilution system. The alkane species of interest was co-injected with toluene to ensure the syringe pump was operating correctly, since an expected signal for toluene can be calculated. The $n$-alkane sen10 sitivity is shown in Fig. 4. The response curve displays a dependence on the drift field strength. Our data reveal that the PTR-MS is insensitive to alkanes with carbon numbers $<\mathrm{C}_{7}$. The increase in sensitivity for alkanes $>\mathrm{C}_{7}$ is consistent with the rate constant measurements of Arnold et al. (1998) which are also shown in the figure. Quantum mechanical calculations of alkane C-C bond proton affinities (PA) reveal that 15 the more central bonds of the molecule have the largest proton affinities and for larger alkanes approach that of water at $166.5 \mathrm{kcal} \mathrm{mole}^{-1}$ (Hunter and East, 2002). The $\mathrm{H}_{3} \mathrm{O}^{+}+n$-alkane reactions appear to be endothermic and explains why the $n$-alkane sensitivity is significantly lower than that of toluene. The normalized sensitivity for dodecane at $80 \mathrm{Td}$ was $2.8 \mathrm{~Hz}$ perppbv per $\mathrm{MHz}_{3} \mathrm{O}^{+}$(ncps) compared to $13 \mathrm{ncps}$ for toluene. The PA of $n$-alkanes appears to plateau for larger alkanes and the $120 \mathrm{Td}$ sensitivity curve suggests a sensitivity plateau as well for $n$-alkanes $>C_{14}$. At the $80 \mathrm{Td}$ condition the $n$-alkane sensitivity is lower than expected. Given the factor of 1.6 increase in reaction time one would expect the sensitivity at $80 \mathrm{Td}$ to be a factor of 1.6 greater than at $120 \mathrm{Td}$ as was observed for toluene. The lower $n$-alkane sensitivity for the lower drift field strength is consistent with an endothermic reaction. The lower $\mathrm{H}_{3} \mathrm{O}^{+}$ion energies at $80 \mathrm{Td}$ result in a lower reaction rate. The $n$-alkane response curve at $80 \mathrm{Td}$ displayed a different shape than the $120 \mathrm{Td}$ condition. This difference was attributed to the greater number of higher $\mathrm{m} / \mathrm{z}$ ions at the $80 \mathrm{Td}$ condition and their lower transmission efficiency through the mass spectrometer. At $120 \mathrm{Td}$ the $n$-alkane

Quantification of diesel exhaust gas phase organics

M. H. Erickson et al.

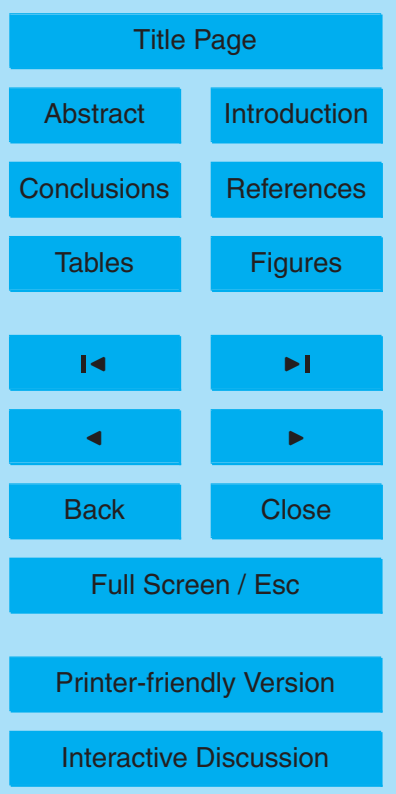


sensitivity is primarily determined by the ion signal at $\mathrm{m} / \mathrm{z} 41,53$ and 57 ions. At $80 \mathrm{Td}$ the sensitivity is determined by broader range of ion masses as shown in Table 1 . The ion signal for alkanes $<\mathrm{C}_{7}$ is likely due to alkane reactions with $\mathrm{O}_{2}^{+}$and $\mathrm{NO}^{+}$in the drift tube since these alkanes have low proton affinities and should not react with $\mathrm{H}_{3} \mathrm{O}^{+}$.

5 Preliminary tests have shown that iso-alkanes (i.e. 2-methylundecane) display similar fragmentation patterns and sensitivity as $n$-alkanes.

\subsection{Mass spectra of gasoline and diesel fuel}

As a surrogate for actual vehicle exhaust, gasoline and diesel fuel were measured by the PTR-MS using the dynamic dilution system to identify constituents that can be measured by the technique. Gasoline contains hydrocarbons in the $C_{4}$ to $C_{10}$ range compared to the $C_{12}$ to $C_{25}$ range for diesel fuel (Han et al., 2008; Schauer et al., 1999). Distinct ion groups were observed in both fuel types that can be related to different organic compound classes. It appears possible to determine the total alkane, aromatic, and alicylic hydrocarbon content in air by measuring a few key ions. Exhausts will be such as aldehydes and furans, and other hydrocarbons such as alkenes, acetylene, and pyrogenic compounds (Han et al., 2008; Vendeuvre et al., 2005, 2007; Wang et al., 2005). Gasoline and diesel fuel test mixtures were generated using the dynamic dilution system with a $5 \mu \mathrm{h} \mathrm{h}^{-1}$ infusion rate and dilution into $20 \mathrm{slpm}$ of dry nitrogen. 20 Both fuels were sampled at 80 and $120 \mathrm{Td}$ drift conditions. Figure 5 depicts the different mass spectra resulting from these samples. Most of the $n$-alkane constituents of gasoline are species that contain less than 8 carbon atoms; approximately $90 \%$ of the alkanes in gasoline emissions are $\mathrm{C}_{8}$ and below (Hoekman, 1992). Since the PTR-MS is relatively insensitive to alkanes with less than 8 carbons it will not observe most of 25 the alkanes present in the gasoline and thus appear to be dominated by alkylbenzene (monoaromatic) compounds. This is evident in the figure. The PTR-MS mass spectrum for gasoline ends around $m / z 180$ while the diesel fuel mass spectrum extends to $m / z$ 240. Gasoline does not have a strong signature at higher $\mathrm{m} / \mathrm{z}$ values while the diesel

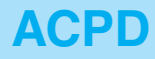

$12,5389-5423,2012$

Quantification of diesel exhaust gas phase organics

M. H. Erickson et al.

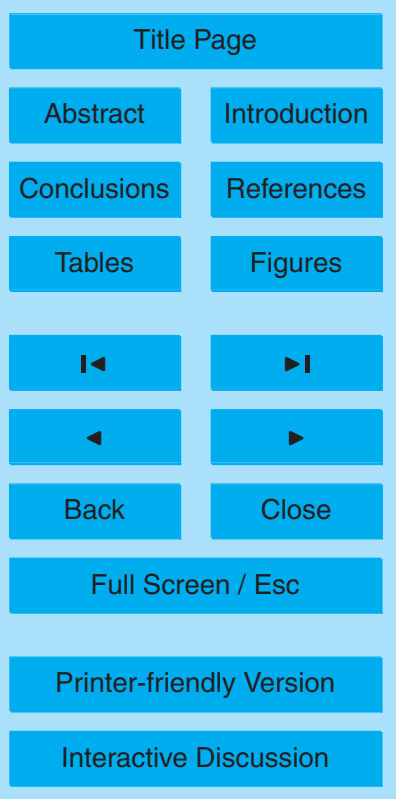


spectra is dominated by higher $\mathrm{m} / \mathrm{z}$ values as expected. For diesel fuel there is clearly more signal at higher ion masses for the $80 \mathrm{Td}$ condition than at $120 \mathrm{Td}$.

The diesel fuel and gasoline mass spectrums were organized into several compound groups listed in Table 2. Both the diesel and gasoline spectra were dominated by the $5 \quad n$-alkane and alkylbenzene groups (monoaromatics) which includes compounds such as the xylene isomers $\left(\mathrm{C}_{2}\right.$-alkylbenzenes $)$ and trimethylbenzenes $\left(\mathrm{C}_{3}\right.$-alkylbenzenes $)$. Alkylbenzene compounds comprise $75 \%$ of the non-ethanol total ion signal of gasoline. Diesel fuel is more dominated by alkanes, which make up approximately $70 \%$ by mass of the fuel (Vendeuvre et al., 2005). Previous measurements of diesel exhaust 10 composition have shown the presence of benzene, toluene, and larger alkylbenzenes (Schauer et al., 1999; Han et al., 2008; Schmitz et al., 2000; Schulz et al., 1999). Alkylbenzenes account for approximately $18 \%$ by mass of the fuel (Vendeuvre et al., 2005). Branched alkanes such as iso-alkanes should also be a significant component of diesel fuel and the $\mathrm{C}_{n} \mathrm{H}_{2 n+1}$ ion signal in Fig. 5 is attributed to both $n$-alkanes and 15 branched alkanes.

An ion group with a formula $\mathrm{C}_{n} \mathrm{H}_{2 n-7}$ makes up $14 \%$ of total diesel fuel ion signal at $80 \mathrm{Td}$ but less than $2 \%$ of the gasoline mass spectra. If this ion signal can be interpreted as an $\mathrm{MW}+1$ mass spectrum then this group could be a series of tetrahydronaphthalenes, differing by the degree of alkyl substitution and size of alkyl groups for $n \geq 12$. These species have not been reported in diesel fuel, but alkyl substituted naphthalenes have been measured (Schauer et al., 1999). About $8 \%$ of the diesel fuel mass spectrum is comprised of an ion group with formula $67+(n \cdot 14)$ where $n$ is the carbon number from $n=0$ to $n=10$. This group contributes less than $1 \%$ of the gasoline spectra. Identification of the species requires further investigation.

25 A prominent group of ions found in both fuels has the formula $\mathrm{C}_{n} \mathrm{H}_{2 n-1}$. This formula corresponds to $\mathrm{m} / \mathrm{z}$ values of $69,83,97,111,125$, etc. These ions may be from naphthenic compounds (alkyl substituted cyclohexanes). The compounds methylcyclohexane and dimethylcyclohexane were found to fragment to ions at $m / z 83,97$, and 111. Interestingly a signal at these masses is observed in polluted urban air as illustrated

Quantification of diesel exhaust gas phase organics

M. H. Erickson et al.

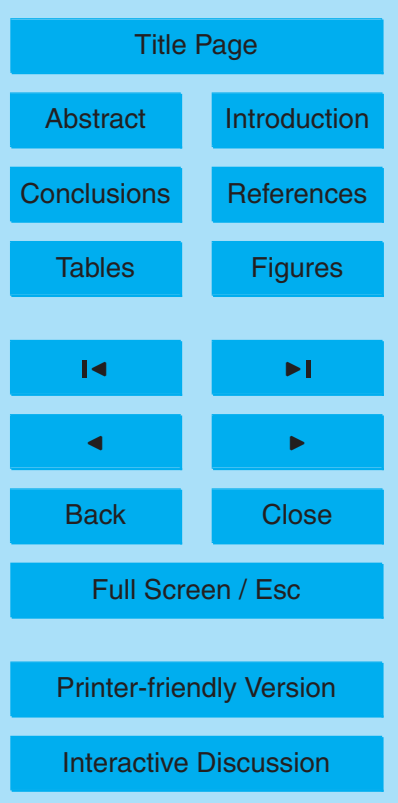


in Fig. 6 which displays a PTR-MS mass scan of Mexico City air done at 120 Td drift condition. Given their abundance in both gasoline and diesel fuels we propose that the $\mathrm{C}_{n} \mathrm{H}_{2 n+1}$ and $\mathrm{C}_{n} \mathrm{H}_{2 n-1}$ ion groups observed in PTR-MS data of urban environments have significant contributions from saturated compounds emitted in vehicle exhausts.

5 A potential way to discriminate between gasoline and diesel exhaust compounds may be to measure the relative abundance of $\mathrm{C}_{n} \mathrm{H}_{2 n+1}$ ions to $\mathrm{C}_{n} \mathrm{H}_{2 n-1}$ ions. Another potential tracer is the $\mathrm{m} / \mathrm{z} 161$ to 85 ratio. The $\mathrm{m} / \mathrm{z} 161$ ion is much more prominent in diesel fuel than in the gasoline. The ratio of $m / z 161$ to 85 is 0.95 for the diesel fuel and only 0.003 for gasoline.

\subsection{Calibration and concentration determination}

In order to translate the thermal desorption signal (area under an ion count rate versus time plot) into concentrations, a multi-point calibration of the thermal desorption system was necessary. Using the dynamic dilution system, known quantities of dodecane were collected on the Tenax trap: $5.92,11.84$, and $23.68 \mathrm{ng}$. The sensitivity for $\mathrm{m} / \mathrm{z}$ $1557,71,85$, and 99 for dodecane were calculated as $90,70,60$, and 18 area counts per nanogram respectively. Due to potential interferences at $\mathrm{m} / \mathrm{z} 57$ and 71 , the responses at $\mathrm{m} / \mathrm{z} 85$ and 99 are more reliable ions for alkane concentration determination. The larger sensitivity for the $\mathrm{m} / \mathrm{z} 85$ ion makes it the best choice for determining long chain alkane concentrations in air. The ambient air concentration was determined by dividing 20 the peak area response by the sensitivity. The difference between the ambient sample and the zero air sample is considered to be the response. The area is then multiplied by the calibration factor (60 area counts per nanogram for dodecane $\mathrm{m} / \mathrm{z} 85$ ) and divided by the sample volume (1.23I) to get a concentration $\left(\mathrm{ngl} \mathrm{I}^{-1}\right)$. Since the majority of diesel fuel alkanes are in the $\mathrm{C}_{9}$ to $\mathrm{C}_{14}$ range $(88 \%)$, dodecane was used as a representative compound to calibrate the PTR-MS for diesel exhaust alkanes.

A comparison between the dodecane sensitivity and an overall diesel fuel alkane sensitivity was performed to assess dodecane's representativeness. In these tests the adsorbent trap was not used so that complete mass scans could be collected by

Quantification of diesel exhaust gas phase organics

M. H. Erickson et al.

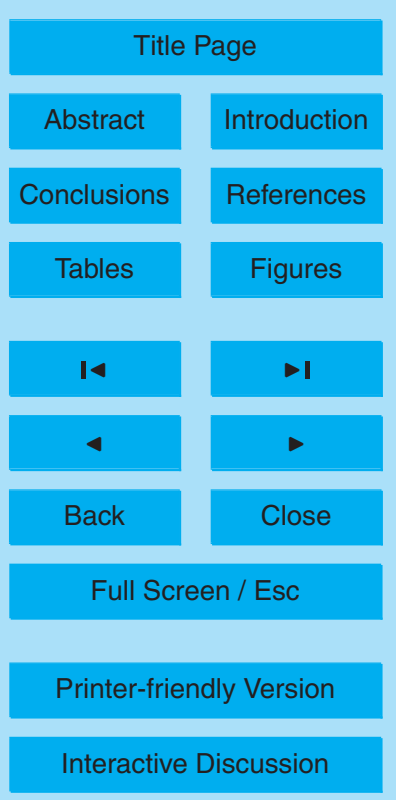


sampling from the dynamic dilution system. In these tests an infusion of $5 \mu \mathrm{h} \mathrm{h}^{-1}$ of diesel fuel or dodecane was diluted into $20 \mathrm{splm}$ of dry nitrogen. Using a density of $0.85 \mathrm{~g} \mathrm{ml}^{-1}$ for diesel fuel and assuming that $70 \%$ by mass is alkane we observed a sensitivity at $\mathrm{m} / \mathrm{z} 85$ of 780 counts $\mathrm{ng}^{-1}$. This compares very well to the dodecane 5 sensitivity of 769 counts per ng and suggests that branched alkanes and $n$-alkanes found in diesel fuel have similar sensitivities. In Fig. 4, the sensitivities of $C_{11}$ to $C_{14} n$ alkanes are similar at $80 \mathrm{Td}$ and these species are thought to make up a large fraction of the overall diesel fuel alkane composition.

\subsection{CARES field campaign}

During June 2010 the PTR-MS measurement method was used during the Carbonaceous Aerosols and Radiative Effects Study (CARES) that took place in Sacramento, CA. The PTR-MS was stationed at American River College in Sacramento, CA and housed in WSU Laboratory for Atmospheric Research's Mobile Atmospheric Chemistry Lab (MACL) with other instruments. A large number of instruments were deployed

15 to measure both gas and particle phase species at this site (Zaveri et al., 2012). IVOCs were measured from 13 to 29 June. The IVOC inlet line consisted of a heated electropolished length of $0.375 \mathrm{~cm}\left(1 / 8^{\prime \prime}\right)$ OD stainless steel tubing with the inlet $3.4 \mathrm{~m}$ above ground. A $2 \mu \mathrm{m}$ Teflon filter was attached to the inlet to remove particles. A flow of $1 \mathrm{slpm}$ was pulled through the inlet at $80^{\circ} \mathrm{C}$ and the PTR-MS subsampled this flow.

OCs were measured by subsampling from a $1.27 \mathrm{~cm}\left(1 / 2^{\prime \prime}\right)$ PFA inlet line mounted at a $10-\mathrm{m}$ height. The VOC sample was dehumidified by passing through a trap at $-30^{\circ} \mathrm{C}$.

Sample collection onto the Tenax adsorbent took $30 \mathrm{~min}$ at a flow rate of $40.5 \mathrm{sccm}$. Desorption took $5 \mathrm{~min}$ at a flow rate of $24 \mathrm{sccm}$ of $\mathrm{N}_{2}$ into the drift tube. The Tenax The desorption temperature was $180^{\circ} \mathrm{C}$. After the desorption was complete, the adsorbent trap was heated to $200^{\circ} \mathrm{C}$ and backflushed with $104 \mathrm{sccm}$ dry $\mathrm{N}_{2}$ flow for $4 \mathrm{~min}$. After the backflush period, the IVOC system was returned to sampling mode.
ACPD

$12,5389-5423,2012$

Quantification of diesel exhaust gas phase organics

M. H. Erickson et al.

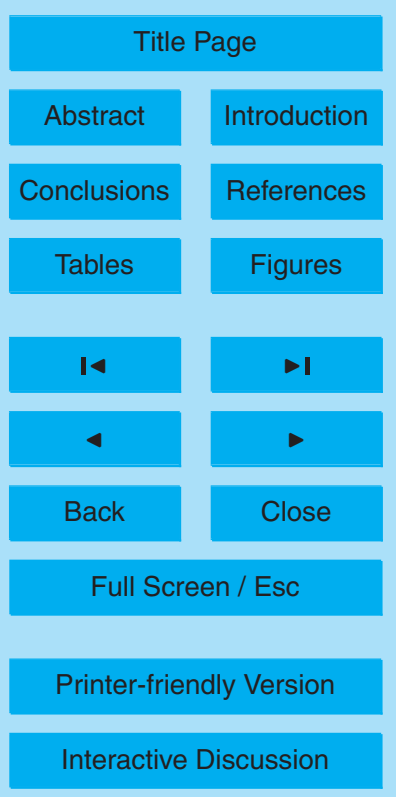


The measurement of VOCs was implemented during the sampling and backflushing modes. During desorption, a total of $120 \mathrm{ml}$ was passed through the Tenax trap. At $180^{\circ} \mathrm{C}$, the breakthrough volumes of dodecane, heptadecane, and octadecane are 17 , 110 , and $180 \mathrm{ml}$ respectively. This means that there is sufficient volume to allow for 5 complete desorption of $\mathrm{C}_{17}$ and lower alkanes. Due to this limitation within the desorption process, the $\mathrm{C}_{18}$ and larger alkanes will not be completely desorbed from the trap.

\section{Field results}

Based on their abundance in the diesel fuel mass spectrum, a series of ions were se10 lected for monitoring in the CARES field campaign. The ions $m / z$ 93, 121 and 135 were selected to measure alkylbenzene abundance with the intention of comparing the IVOC response for these ions to the VOC mode response. To test the accuracy of the IVOC desorption system in the field, a peak area calibration curve was developed for toluene $(\mathrm{m} / \mathrm{z}$ 93) using the same gas standard utilized during the calibrations of the standard 15 VOC inlet. The calibration was then applied to the $\mathrm{m} / \mathrm{z} 93$ peak areas measured in IVOC mode and compared to the toluene concentrations measured in VOC mode. A plot of VOC measured toluene vs. IVOC measured toluene yielded a slope of 1.043 and an $r^{2}$ of 0.605 resulted. This reasonable agreement shows that the peak integration and calibration method utilized is sufficient enough to yield comparable concentrations.

20 A similar approach was applied to the $\mathrm{m} / \mathrm{z} 121$ ion $\left(\mathrm{C}_{3}\right.$-alkylbenzenes) and the $\mathrm{m} / \mathrm{z}$ 135 ion $\left(\mathrm{C}_{4}\right.$-alkylbenzenes). Comparison between IVOC and VOC data for these ions showed poor agreement, with the IVOC system concentrations being 3 times higher than the VOC system concentrations. This difference was attributed to fragmentation of larger alkylbenzenes to $\mathrm{m} / \mathrm{z} 121$ and 135 . Most of the alkylbenzenes in diesel fuel are larger than $\mathrm{C}_{4}$-alkylbenzenes (Vendeuvre et al., 2005). Larger alkylbenzenes will not pass through the $-30^{\circ} \mathrm{C}$ water trap used in VOC sampling and thus would not contribute to the VOC signal. The IVOC sampler efficiently collects these species, and fragmentation appears to produce significant ion signal at the $m / z 121$ and 135 . This

Quantification of diesel exhaust gas phase organics

M. H. Erickson et al.

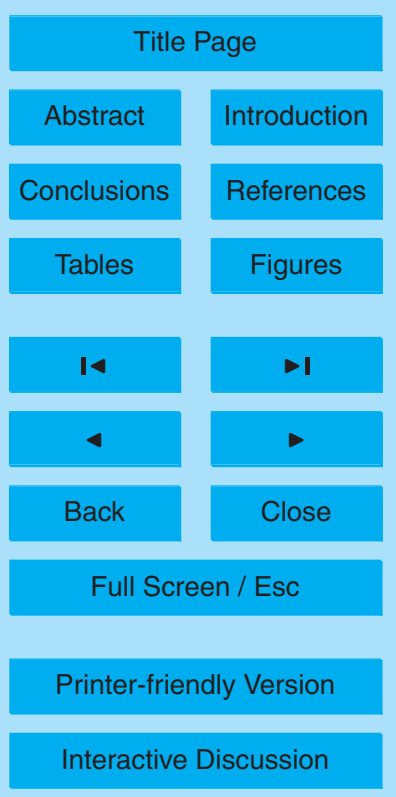


is an interesting result and suggests there is a large pool of heavy alkylbenzenes that would be of importance as SOA precursors, qualitatively consistent with observations by Lewis et al. (2000).

The ions $57,71,85$, and $99\left(\mathrm{C}_{n} \mathrm{H}_{2 n+1}\right)$ were chosen to measure alkane abundance.

5 The area count response for these ions together with $\mathrm{NO}_{\mathrm{x}}$ mixing ratios averaged over the IVOC sampling time are shown in Fig. 7. In general the ions covaried with each other and tracked variations in $\mathrm{NO}_{\mathrm{x}}$. The $\mathrm{m} / \mathrm{z} 57$ and 71 ions displayed greater diel variability than the $\mathrm{m} / \mathrm{z} 85$ ion, especially in the later part of the measurement period and likely indicates that species other than long chain alkanes produce significant ion 10 signal at these masses. The $\mathrm{m} / \mathrm{z} 99$ ion displayed the overall highest count rates, with the largest count rates occurring during a pollution episode on 28 June.

The ions 97, 111, 125, and 139 from the $\mathrm{C}_{n} \mathrm{H}_{2 n-1}$ group were also monitored and their response is displayed in Fig. 8 along with measured mixing ratios of $\mathrm{C}_{2}$ - and $\mathrm{C}_{3^{-}}$ alkylbenzenes measured in VOC mode. We note that nopinone, a product of the ozone 15 reaction with $\beta$-pinene, also occurs at $m / z 139$ and may be an interferent. There was significant signal for the $m / z 97,111$, and 125 ions. These ions were observed in both diesel fuel and gasoline and may be unique tracers of engine exhaust as there are few VOC species that produce ions at these masses in the PTR-MS. In general there was a good correlation between these masses and they displayed a similar pattern of variability as the $\mathrm{C}_{n} \mathrm{H}_{2 n+1}$ ion group. The $\mathrm{m} / \mathrm{z} 97$ ion displayed the largest response of this group. During the clean air period experienced on 20 June the response of the $\mathrm{C}_{n} \mathrm{H}_{2 n-1}$ and the $\mathrm{C}_{n} \mathrm{H}_{2 n+1}$ ions were often at the detection limit of the method. Elevated counts for all these ions were observed on 17, 21, and 28 June corresponding to periods of elevated $\mathrm{NO}_{x}$ and $\mathrm{C}_{2}$ and $\mathrm{C}_{3}$ - alkylbenzenes. The similarity in temporal 25 variability of these ion groups and their correspondence with $\mathrm{NO}_{\mathrm{x}}$ and alkylbenzene variation suggests these ion groups represent species emitted in roadway exhaust. Figure 9 shows the correlation between the $\mathrm{m} / \mathrm{z} 85$ and 97 ions. The slope of the plot was 0.74 with an $r^{2}$ of 0.880 . The observed ambient ratio between these ions matches the ratio in the diesel fuel mass spectrum of 0.75 . The ratio for gasoline

Quantification of diesel exhaust gas phase organics

M. H. Erickson et al.

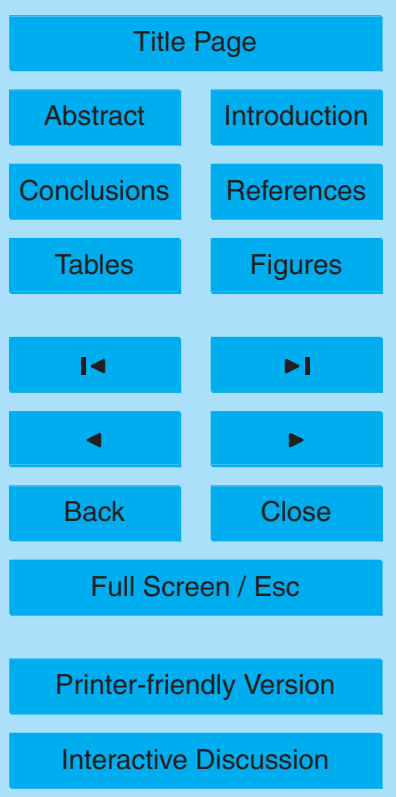


was significantly smaller at 0.21 . The good match between ambient ratios and the diesel fuel mass spectrum provides evidence that these ions are good tracers of diesel exhaust abundance in air.

The IVOC alkane concentrations were calculated from the $\mathrm{m} / \mathrm{z} 85$ ion signal inten5 sity using the dodecane response factor. This ion was used because there is no suspected potential for VOC interference as is the case for $\mathrm{m} / \mathrm{z} 57$ and 71 . The resulting alkane concentration timeseries is displayed in Fig. 10 along with total alkylbenzene species concentration measured by the PTR-MS in VOC mode. These species include toluene, $\mathrm{C}_{2}$-alkylbenzenes (xylenes and ethylbenzene) and $\mathrm{C}_{3}$-alkylbenzenes 10 (trimethylbenzene isomers, ethyltoluene isomers, propylbenzene isomers), and are good tracers of spark ignition vehicle exhaust and important SOA precursors. The total alkane concentration determined by this approach was significantly greater than the measured VOC alkylbenzene concentrations. There was a reasonable correlation $\left(r^{2}\right.$ of 0.584 ) between the IVOC alkanes and VOC alkylbenzenes; the data were bounded by alkane/alkylbenzene ratio limits of 5 and 15. The average alkane to alkylbenzene ratio was $10.0 \pm 6.1$ and the median ratio was 9.1. The total IVOC alkane concentration calculated seems surprisingly high and implies a substantial and important pool of carbon for SOA formation. This alkane to alkylbenzene ratio can be compared to that observed in the traffic tunnel studies of Zeilinska et al. (1996). In that study $\mathrm{C}_{10}-\mathrm{C}_{13}$ $n$-alkanes were measured, a reasonably proxy for the IVOC alkanes. The sum of these $n$-alkanes to toluene was found to yield a ratio of 0.13 in a tunnel dominated by spark ignition vehicle traffic and 1.2 in a tunnel dominated by diesel traffic. The CARES data yields an average alkane to toluene concentration ratio of 15 . The PTR-MS is sensitive to branched IVOC alkanes and thus quantifies the total IVOC alkane abundance so this ratio should be higher than that measured by Zeilinska et al. (1996). It is also likely that due to reductions in spark ignition exhaust emissions that any measure of diesel exhaust gas phase organics to spark ignition exhaust gas phase organic concentrations will be higher now than in the mid 1990's.
Quantification of diesel exhaust gas phase organics

M. H. Erickson et al.

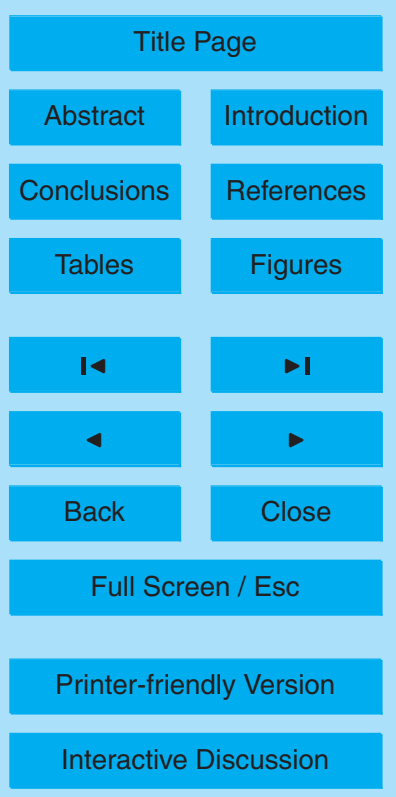


A factor that contributes to the uncertainty of the IVOC alkane concentration is the PTR-MS calibration. The dodecane sensitivity factor used has an estimated uncertainty of $10 \%$ based on experimental repetition of the calibration with dodecane. As discussed in Sect. 2.4 the dodecane sensitivity was very similar to the alkane sensitiv5 ity using diesel fuel itself as a standard. We believe the calibration factor used in the calculation is reliable, at least as it applies to diesel fuel. The calculation of the IVOC alkane abundance assumes that $\mathrm{m} / \mathrm{z} 85$ is a unique tracer for the alkanes that comprise diesel exhaust but the potential exists for positive interferences from other compounds from other sources that are inherently more sensitive due to having a larger proton 10 affinity than alkanes. We note that the $\mathrm{C}_{n} \mathrm{H}_{2 n-1}$ ion group displayed a good correlation with the alkane ions and these may be a more unique set to better determine diesel exhaust gas phase organic concentrations.

The other ions measured by PTR-MS were $\mathrm{m} / \mathrm{z} 143$ and 161 . The $\mathrm{m} / \mathrm{z} 143$ ion corresponds to methylnaphthalene while the $\mathrm{m} / \mathrm{z} 161$ ion was a dominant signal in the diesel fuel mass spectrum but not abundant in gasoline. Figure 11 displays the time series for these ions. Compared to the $\mathrm{C}_{n} \mathrm{H}_{2 n+1}$ and $\mathrm{C}_{n} \mathrm{H}_{2 n-1}$ ion group abundance the 161 response was small and hard to quantify. The $m / z 143$ ion was not above detection limits for the first part of the measurement period but displayed a significant response during the latter half. Its temporal variability suggests that it is not methylnaphthalene from vehicle exhaust but rather a photooxidation product. If the response at $\mathrm{m} / \mathrm{z} 143$ was methylnaphthalene its variation would be expected to track IVOC alkanes. The 143 mass signal intensity follows the daily variation of the photoproducts $\mathrm{NO}_{z}\left(\mathrm{NO}_{\mathrm{y}}-\mathrm{NO}_{\mathrm{x}}\right)$ and $\mathrm{HCHO}$ with distinct daytime maxima and early morning minima as shown in the figure. This ion may be due to nonanal which could be created through ozone reactions with organics adsorbed onto inlet line surfaces (McClenny et al., 1998). We note that aldehydes such as heptanal and octanal may yield fragment ions at $\mathrm{m} / \mathrm{z} 97$ and 111 and perhaps produce the diel pattern evident in Fig. 8 for 25 and 26 June. While there is some dispute about the concentration of long chain aldehydes in ambient air, this type of sampling interference may be problematic for measuring methylnaphthalene

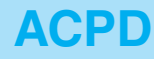

12, 5389-5423, 2012

\section{Quantification of diesel exhaust gas phase organics}

M. H. Erickson et al.

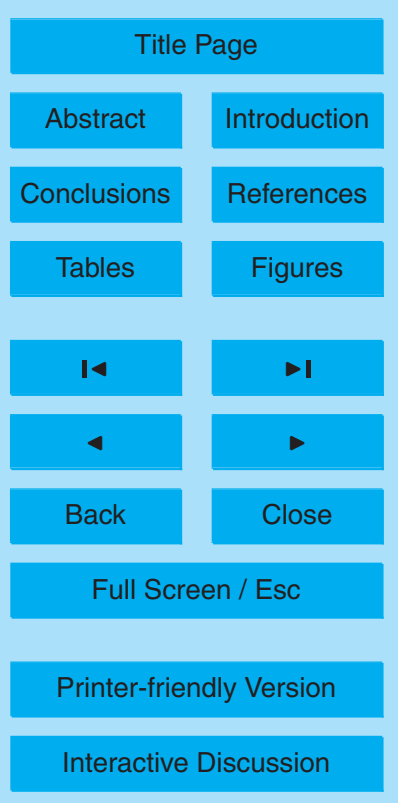


and ions from the $\mathrm{C}_{n} \mathrm{H}_{2 n-1}$ group observed in diesel fuel.

\section{Conclusions}

Laboratory experiments show the PTR-MS is sensitive to alkanes larger than $\mathrm{C}_{8}$. The sensitivity is less than expected if these compounds have proton affinities greater than

$5 \mathrm{H}_{2} \mathrm{O}$. Normalized sensitivity for dodecane at $120 \mathrm{Td}$ was $3.2 \mathrm{ncps}$ while at $80 \mathrm{Td}$ it was 2.8 ncps. At $80 \mathrm{Td}$ the sensitivity to dodecane was $22 \%$ that of toluene. For $n$-alkanes with less than 6 carbon atoms there is no apparent reaction with $\mathrm{H}_{3} \mathrm{O}^{+}$. The $n$-alkanes were shown to fragment to a common set of ions with formula $\mathrm{C}_{n} \mathrm{H}_{2 n+1}$ as well as $m / z$ 41. The relative intensity of the fragment ions was a function of drift field strength. At 10 lower Td values more ion intensity occurred in larger masses. Analysis of diesel fuel by PTR-MS shows the fuel is dominated by alkanes as expected but with significant abundance of alkylbenzenes (up to a mass of $240 \mathrm{amu}$ ). Also prominent in the mass spectrum were ions with the formula $\mathrm{C}_{n} \mathrm{H}_{2 n-1}(\mathrm{~m} / \mathrm{z} 97,111,125$, etc.).

A thermal desorption sampler was added to the PTR-MS drift tube, allowing for nor15 mal VOC measurements as well as sample collection and desorption of heavier organics from a Tenax TA adsorbent. In this analytical approach the PTR-MS drift tube was operated at $80 \mathrm{Td}$ for both VOC sampling and thermal desorption analysis. In VOC analysis mode the air sample was passed through a $-30^{\circ} \mathrm{C}$ water vapor trap which also prevents passage of heavier organics. The thermal desorption sampler in turn discriminated against VOC compounds by using a high temperature purge before direct desorption into the PTR-MS drift tube using dry $\mathrm{N}_{2}$ carrier gas. PTR-MS field measurements were made over a period of 12 days in Sacramento, CA. as part of the CARES field experiment. Normal continuous VOC analysis alternated with thermal desorption sampling/analysis. The thermal desorption sample was collected for $30 \mathrm{~min}$, every hour, and ran continuously for 12 days. A number of ions were monitored in the thermal desorption samples including $\mathrm{C}_{n} \mathrm{H}_{2 n+1}$ ions $(57,71,85,99)$ and $\mathrm{C}_{n} \mathrm{H}_{2 n-1}$ ions $(97,111,125,139)$ and both ion groups displayed temporal variability

Quantification of diesel exhaust gas phase organics

M. H. Erickson et al.

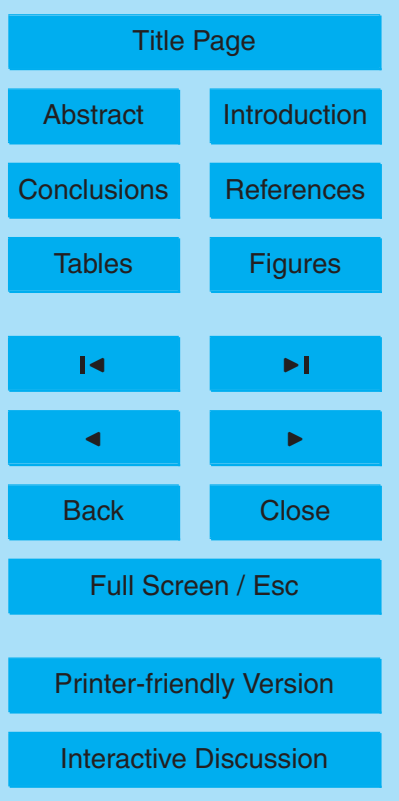


that corresponded with $\mathrm{NO}_{x}$ and VOC alkylbenzenes. The ratio of the $m / z 97$ to 85 ion response matched that found in the analysis of diesel fuel, suggesting diesel exhaust compounds as the source. Using the dodecane sensitivity for the $\mathrm{m} / \mathrm{z} 85$ ion, we calculated a total diesel exhaust alkane concentration based on the $\mathrm{m} / \mathrm{z} 85$ abundance.

5 The alkane concentration ranged from the detection limit of the method of $\sim 1 \mu \mathrm{g} \mathrm{m}^{-3}$ to over $100 \mathrm{\mu g} \mathrm{m}^{-3}$ during several air pollution episodes. The calculated alkane concentration was on average about a factor of 10 higher than the total VOC alkylbenzene concentration, with an observed range of between 5 and 15 . We conclude that PTRMS analysis of diesel exhaust alkanes is a viable approach for providing quantitative - information on their total abundance in urban air and hence on their importance as SOA precursors. Further work is necessary to verify the fidelity of $m / z 85,99,97,111$, 125 ions from thermal desorption sampling as tracers of diesel exhaust organics in urban environments.

Acknowledgements. This research was supported by the Office of Science (BER) U.S. Depart15 ment of Energy, Grant No. DE-FG02-08ER64626.

\section{References}

Arnold, S. T., Viggiano, A. A., and Morris, R. A.: Rate Constants and Product Branching Fractions for the Reactions of $\mathrm{H}_{3} \mathrm{O}^{+}$and $\mathrm{NO}^{+}$with $\mathrm{C}_{2}-\mathrm{C}_{12}$ Alkanes, J. Phys. Chem., A 102, 8881-8887, doi:10.1021/jp9815457, 1998.

20 Bohme, D. K., Mackay, G. I., and Tanner, S. D.: An Experimental Study of the Gas-Phase Kinetics of Reactions with Hydrated $\mathrm{H}_{3} \mathrm{O}^{+}$Ions $(n=1-3)$ at $298 \mathrm{~K}$, J. Am. Chem. Soc., 101, 3724-3730, 1979.

De Gouw, J. A., Middlebrook, A. M. Warneke, C., Goldan, P. D., Kuster, W. C., Roberts, J. M., Fehsenfeld, F. C., Worsnop, D. R., Canagaratna, J. M., Pszenny, A. A. P., Keene, W. C., Marchewka, M., Bertman, S. B., and Bates, T. S.: Budget of organic carbon in a polluted atmosphere: Results from the New England Air Quality Study in 2002, J. Geophys. Res.Atmos., 110, D16305, doi:10.1029/2004JD005623, 2005.

\section{ACPD}

$12,5389-5423,2012$

Quantification of diesel exhaust gas phase organics

M. H. Erickson et al.

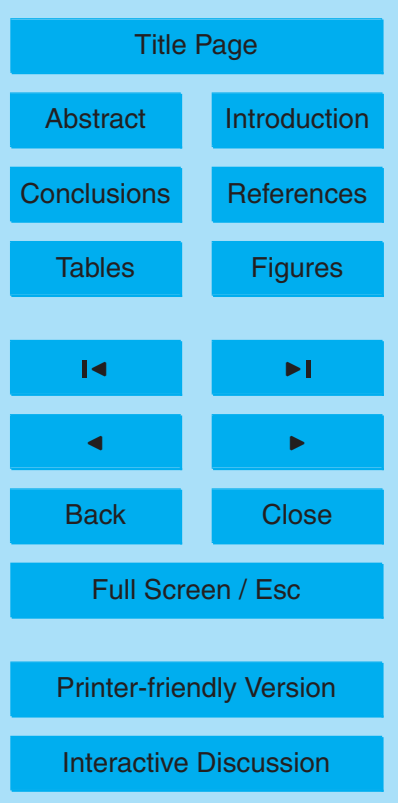


Fast, J. D., Gustafson Jr., W. I., Berg, L. K., Shaw, W. J., Pekour, M., Shrivastava, M., Barnard, J. C., Ferrare, R. A., Hostetler, C. A., Hair, J. A., Erickson, M., Jobson, B. T., Flowers, B., Dubey, M. K., Springston, S., Pierce, R. B., Dolislager, L., Pederson, J., and Zaveri, R. A.: Transport and mixing patterns over Central California during the Carbonaceous Aerosol and Radiative Effects Study (CARES), Atmos. Chem. Phys. Discuss., 11, 29949-30008, doi:10.5194/acpd-11-29949-2011, 2011.

Han, M., Assanis, D. N., Jacobs, T. J., and Bohac, S. V.: Method and Detailed Analysis of Individual Hydrocarbon Species From Diesel Combustion Modes and Diesel Oxidation Catalyst, J. Eng. Gas. Turb. Power, 130, 042803-1-042803-10, 2008.

10 Heald, C. L., Jacob, D. J., Park, R. J., Russel, L. M., Huebert, B. J., Seinfeld, J. H., Liao, H., and Weber, R. J.: A large organic aerosol source in the free troposphere missing from current models, Geophys. Res. Lett., 32, L18809, doi:10.1029/2005GL023831, 2005.

Hoekman, S. K.: Speciated Measurements and Calculated Reactivities of Vehicle Exhaust Emissions from Conventional and Reformulated Gasolines, Environ. Sci. Technol., 26, 12061216, doi:10.1021/es50002a610, 1992.

Hunter, K. C. and East, A. L. L.: Properties of C-C Bonds in $n$-alkanes: Relevance to Cracking Mechanisms, J. Phys. Chem. A., 106, 1346-1356, doi:10.1021/jp0129030, 2002.

Jobson, B. T. and McCoskey, J. K.: Sample drying to improve HCHO measurements by PTRMS instruments: laboratory and field measurements, Atmos. Chem. Phys., 10, 1821-1835, doi:10.5194/acp-10-1821-2010, 2010.

Jobson, B. T., Alexander, M. L., Maupin, G. D., and Muntean, G. G.: On-line analysis of organic compounds in diesel exhaust using a proton transfer reaction mass spectrometer (PTR-MS), Int. J. Mass. Spectrom., 245, 78-89, doi:10.1016/j.jjms.2005.05.009, 2005.

Johnson, K. S., Zuberi, B., Molina, L. T., Molina, M. J., ledema, M. J., Cowin, J. P., Gaspar, D. J., Wang, C., and Laskin, A.: Processing of soot in an urban environment: case study from the Mexico City Metropolitan Area, Atmos. Chem. Phys., 5, 3033-3043, doi:10.5194/acp-53033-2005, 2005.

Jordan, C. E., Ziemann, P. J., Griffin, R. J., Lim Y. B., Atkinson, R., and Arey, J.: Modeling SOA formation from $\mathrm{OH}$ reactions with $\mathrm{C}_{8}-\mathrm{C}_{17} n$-alkanes, Atmos. Environ., 42, 8015-8026, doi:10.1016/j.atmosenv.2008.06.017, 2008.

Lai, C. H., Chen, K. S., Ho, Y. T., and Chou, M. S.: Characteristics of $\mathrm{C}_{2}-\mathrm{C}_{15}$ hydrocarbons in the air of urban Kaohsiung, Taiwan, Atmos. Environ., 28, 1997-2011, doi:10.1016/j.atmosenv.2003.11.041, 2004.
12, 5389-5423, 2012

Quantification of diesel exhaust gas phase organics

M. H. Erickson et al.

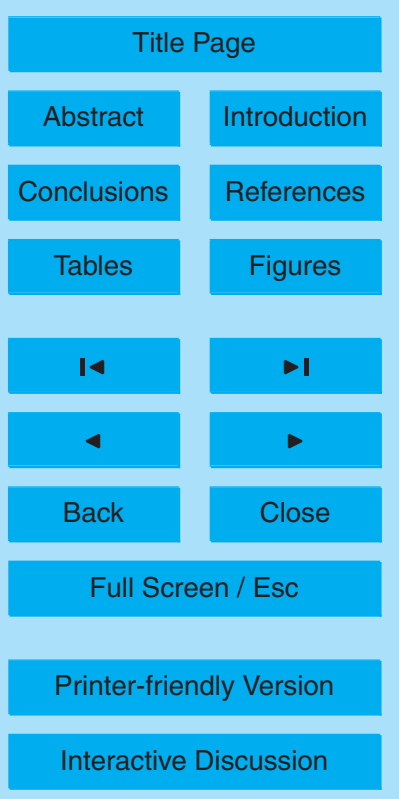

Interactive Discussion 
Lewis, A. C., Carslaw, N., Marriott, P. J., Kinghorn, R. M., Morrison, P., Lee, A. L., Bartle, K. D., and Pilling, M. J.: A larger pool of ozone forming carbon compounds in urban atmospheres, Nature, 405, 778-781, 2000.

Lias, S. G., Liebman, J. F., and Levin, R. D.: Evaluated Gas Phase Basicities and Proton 5 Affinities of Molecules; Heats of Formation of Protonated Molecules, J. Phys. Chem. Ref. Data, 13, 695-808, 1984.

Lim, Y. B. and Ziemann, P. J.: Products and Mechanism of Secondary Organic Aerosol Formation from Reactions of $n$-alkanes with $\mathrm{OH}$ radicals in the Presence of $\mathrm{NO}_{\mathrm{x}}$, Environ. Sci. Technol., 39, 9229-9236, doi:10.1021/es051447g, 2005.

10 McClenny, W. A., Daughtrey Jr., E. H., Adams, J. R., Oliver, K. D., and Kronmiller, K. G.: Volatile organic compound concentration patterns at the New Hendersonville monitoring site in the 1995 Southern Oxidants Study in the Nashville, Tennessee, area, J. Geophys. Res., 103, 22509-22518, 1998.

Presto, A. A., Miracolo, M. A., Kroll, J. H., Worsnop, D. R., Robinson, A. L., and Donahue, N.

15 M.: Intermediate- Volatility Organic Compounds: A Potential Source of Ambient Oxidized Organic Aerosol, Environ. Sci. Technol., 43, 4744-4749, doi:10.1021/es803219q, 2009.

Robinson, A. L., Donahue, N. M., Shrivastava, M. K., Weitkamp, E. A., Sage, A. M., Grieshop, A. P., Lane, T. E., Pierce, J. R., and Pandis, S. N.: Rethinking Organic Aerosol: Semivolatile Emissions and Photochemical Aging, Science, 315, 1259-1262, doi:10.1126/science.1133061, 2007.

Samy, S. and Zielinska, B.: Secondary organic aerosol production from modern diesel engine emissions, Atmos. Chem. Phys., 10, 609-625, doi:10.5194/acp-10-609-2010, 2010.

Schauer, J. J., Kleeman, M. J., Cass, G. R., and Simoneit, B. R. T.: Measurement of Emissions from Air Pollution Sources. 2. C1 through C30 Organic Compounds from Medium Duty Diesel Trucks, Environ. Sci. Technol., 33, 1578-1587, doi:10.1021/es980081n, 1999.

Schmitz, T., Hassel, D., and Weber, F.-J.: Determination of VOC-components in the exhaust of gasoline and diesel passenger cars, Atmos. Environ., 34. 4639-4647, 2000.

Schulz, H., Bandeira del Melo, G., and Ousmanov, F.: Volatile Organic Compounds and Particulates as Components of Diesel Engine Exhaust Gas, Combust. Flame, 118, 179-190, 1999.

Siegl, W. O., Hammerle, R. H., Herrmann, H. M., Wenclawiak, B. W., and Luers-Jongen, B.: Organic emissions profile for a light-duty diesel vehicle, Atmos. Environ., 33, 797-805, 1999. Spanel, P. and Smith, D.: Selected ion flow tube studies of the reactions of $\mathrm{H}_{3} \mathrm{O}^{+}, \mathrm{NO}^{+}$, and $\mathrm{O}_{2}^{+}$

Quantification of diesel exhaust gas phase organics

M. H. Erickson et al.

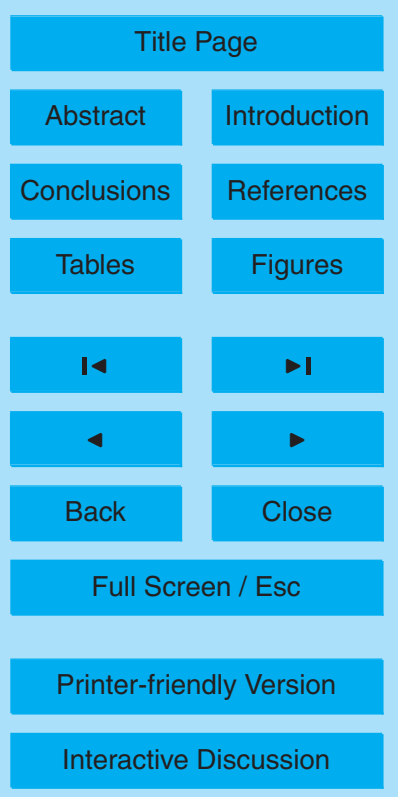


with several aromatic and aliphatic hydrocarbons, Int. J. Mass Spectrom., 181, 1-10, 1998.

Vendeuvre, C., Ruiz-Guerrero, R., Bertoncini, F., Duval, L., Thiebaut, D., and Hennion, M. C.: Characterization of middle-distillates by comprehensive two-dimensional gas chromatography $(G C \times G C)$ : A powerful alternative for performing various standard analysis of middledistillates, J. Chromatogr. A, 1086, 21-28, doi:10.1016/j.chroma.2005.05.106, 2005.

Vendeuvre, C., Ruiz-Guerrero, R., Bertoncini, F., Duval, L., and Thiebaut, D.: Comprehensive Two-Dimensional Gas Chromatography for Detailed Characterisation of Petroleum Products, Oil Gas Sci. Technol., 62, 43-55, doi:10.1016/j.chroma.2005.05.106, 2007.

Volkamer, R., Jimenez, J. L., San Martini, F., Dzepina, K., Zhang, Q., Salcedo, D., Molina, L. T., Worsnop, D. R., and Molina, M. J.: Secondary organic aerosol formation from anthropogenic air pollution: Rapid and higher than expected, Geophys. Res. Lett., 33, L17811, doi:10.1029/2006GL026899, 2006.

Wang, C.-Y. F., Qian, K., and Green, L. A.: GCxMS of Diesel: A Two-Dimensional Separation Approach, Anal. Chem., 77, 2777-2785, doi:10.1021/ac0401624, 2005.

Zaveri, R. A., Shaw, W. J., Cziczo, D. J., Schmid, B., Ferrare, R. A., Alexander, M. L., Alexandrov, M., Alvarez, R. J., Arnott, W. P., Atkinson, D. B., Baidar, S., Banta, R. M., Barnard, J. C., Beranek, J., Berg, L. K., Brechtel, F., Brewer, W. A., Cahill, J. F., Cairns, B., Cappa, C. D., Chand, D., China, S., Comstock, J. M., Dubey, M. K., Easter, R. C., Erickson, M. H., Fast, J. D., Floerchinger, C., Flowers, B. A., Fortner, E., Gaffney, J. S., Gilles, M. K., Gorkowski, K., Gustafson, W. I., Gyawali, M., Hair, J., Hardesty, R. M., Harworth, J. W., Herndon, S., Hiranuma, N., Hostetler, C., Hubbe, J. M., Jayne, J. T., Jeong, H., Jobson, B. T., Kassianov, E. I., Kleinman, L. I., Kluzek, C., Knighton, B., Kolesar, K. R., Kuang, C., Kubátová, A., Langford, A. O., Laskin, A., Laulainen, N., Marchbanks, R. D., Mazzoleni, C., Mei, F., Moffet, R. C., Nelson, D., Obland, M. D., Oetjen, H., Onasch, T. B., Ortega, I., Ottaviani, M., Pekour, M., Prather, K. A., Radney, J. G., Rogers, R. R., Sandberg, S. P., Sedlacek, A., Senff, C. J., Senum, G., Setyan, A., Shilling, J. E., Shrivastava, M., Song, C., Springston, S. R., Subramanian, R., Suski, K., Tomlinson, J., Volkamer, R., Wallace, H. W., Wang, J., Weickmann, A. M., Worsnop, D. R., Yu, X.-Y., Zelenyuk, A., and Zhang, Q.: Overview of the 2010 Carbonaceous Aerosols and Radiative Effects Study (CARES), Atmos. Chem. Phys. Discuss., 12, 1299-1400, doi:10.5194/acpd-12-1299-2012, 2012.

Zielinska, B., Sagebiel, J. C., Harshfield, G., Gertler, A. W., and Pierson, W. R.: Volatile Organic Compounds up to C20 Emitted from Motor Vehicles; Measurement Methods, Atmos. Environ., 30, 2269-2286, 1996. 
Table 1. The percentage of total ion abundance of fragment ions $\mathrm{C}_{n} \mathrm{H}_{2 n+1}$ from $n$-alkanes at $80 \mathrm{Td}$.

\begin{tabular}{rrrrrrrrrrr}
\hline$n$ & $m / z$ & $\mathrm{C}_{8}$ & $\mathrm{C}_{9}$ & $\mathrm{C}_{10}$ & $\mathrm{C}_{11}$ & $\mathrm{C}_{12}$ & $\mathrm{C}_{13}$ & $\mathrm{C}_{14}$ & $\mathrm{C}_{15}$ & $\mathrm{C}_{16}$ \\
\hline 3 & 43 & $4 \%$ & $3 \%$ & $2 \%$ & $2 \%$ & $1 \%$ & $1 \%$ & $1 \%$ & $1 \%$ & $2 \%$ \\
4 & 57 & $39 \%$ & $21 \%$ & $24 \%$ & $28 \%$ & $27 \%$ & $26 \%$ & $25 \%$ & $24 \%$ & $24 \%$ \\
5 & 71 & $41 \%$ & $44 \%$ & $30 \%$ & $25 \%$ & $24 \%$ & $23 \%$ & $22 \%$ & $22 \%$ & $21 \%$ \\
6 & 85 & $13 \%$ & $26 \%$ & $33 \%$ & $26 \%$ & $22 \%$ & $20 \%$ & $18 \%$ & $17 \%$ & $18 \%$ \\
7 & 99 & $1 \%$ & $3 \%$ & $7 \%$ & $11 \%$ & $10 \%$ & $9 \%$ & $8 \%$ & $8 \%$ & $7 \%$ \\
8 & 113 & $1 \%$ & $0 \%$ & $2 \%$ & $5 \%$ & $8 \%$ & $8 \%$ & $8 \%$ & $7 \%$ & $6 \%$ \\
9 & 127 & & $2 \%$ & $0 \%$ & $2 \%$ & $4 \%$ & $7 \%$ & $7 \%$ & $7 \%$ & $6 \%$ \\
10 & 141 & & & $1 \%$ & $0 \%$ & $1 \%$ & $3 \%$ & $6 \%$ & $6 \%$ & $5 \%$ \\
11 & 155 & & & & $1 \%$ & $0 \%$ & $1 \%$ & $2 \%$ & $4 \%$ & $4 \%$ \\
12 & 169 & & & & & $1 \%$ & $0 \%$ & $1 \%$ & $2 \%$ & $3 \%$ \\
13 & 183 & & & & & & $1 \%$ & $0 \%$ & $0 \%$ & $1 \%$ \\
14 & 197 & & & & & & & $1 \%$ & $0 \%$ & $1 \%$ \\
15 & 211 & & & & & & & & $1 \%$ & $0 \%$ \\
16 & 225 & & & & & & & & $1 \%$ \\
\hline
\end{tabular}

\section{ACPD}

$12,5389-5423,2012$

\section{Quantification of diesel exhaust gas phase organics}

M. H. Erickson et al.

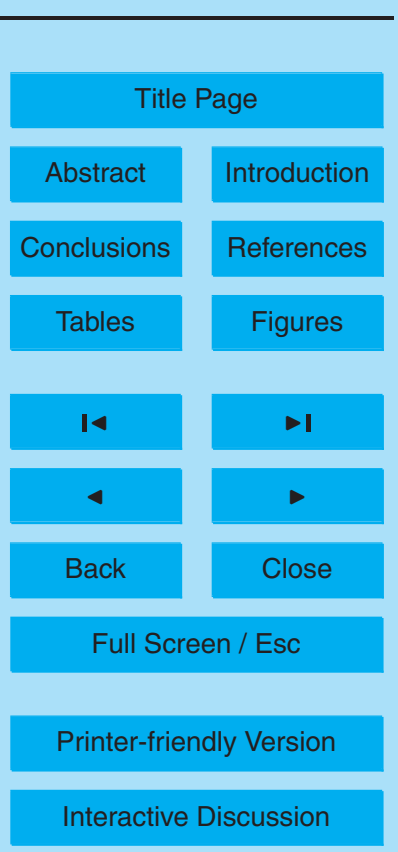




\section{ACPD}

12, 5389-5423, 2012

\section{Quantification of diesel exhaust gas phase organics}

Table 2. Percent of total ion signal for the different groups in diesel and gasoline fuels.

\begin{tabular}{lrrrrr}
\hline \multirow{2}{*}{ Group } & & \multicolumn{2}{c}{ Diesel } & \multicolumn{2}{c}{ Gasoline } \\
& Formula & $\mathrm{Td}=120$ & $\mathrm{Td}=80$ & $\mathrm{Td}=120$ & $\mathrm{Td}=80$ \\
\hline Alkanes & $\mathrm{C}_{n} \mathrm{H}_{2 n+1}$ & $43.3 \%$ & $23.2 \%$ & $36.8 \%$ & $31.1 \%$ \\
Unknown & $\mathrm{C}_{n} \mathrm{H}_{2 n-1}$ & $17.1 \%$ & $17.7 \%$ & $5.3 \%$ & $5.4 \%$ \\
alkyl benzenes & $79+(n \cdot 14)$ & $10.5 \%$ & $20.1 \%$ & $47.9 \%$ & $42.2 \%$ \\
Unknown & $67+(n \cdot 14)$ & $8.2 \%$ & $8.2 \%$ & $0.6 \%$ & $0.5 \%$ \\
Unknown & $\mathrm{C}_{n} \mathrm{H}_{2 n-7}$ & $7.4 \%$ & $14.3 \%$ & $1.7 \%$ & $1.4 \%$ \\
Unknown & $131+(n \cdot 14)$ & $0.8 \%$ & $1.7 \%$ & $0.1 \%$ & $0.1 \%$ \\
naphthalenes & $139+(n \cdot 14)$ & $0.8 \%$ & $1.7 \%$ & $0.9 \%$ & $1.3 \%$ \\
Sum of Signal & & $88 \%$ & $87 \%$ & $93 \%$ & $82 \%$ \\
\hline
\end{tabular}

M. H. Erickson et al.

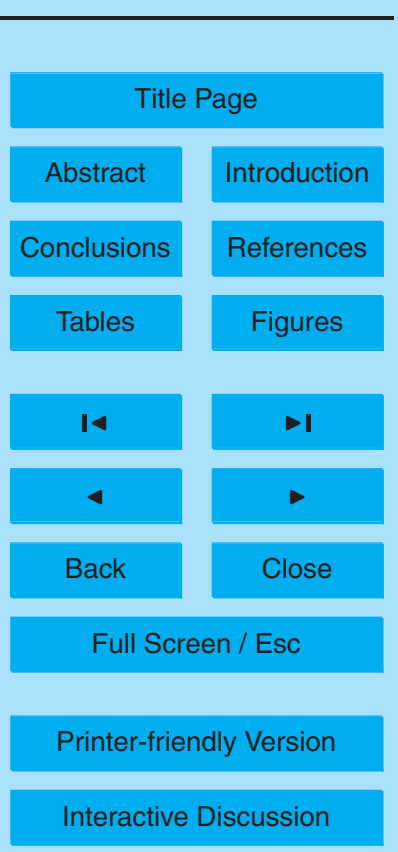




\section{ACPD}

$12,5389-5423,2012$

\section{Quantification of diesel exhaust gas phase organics}

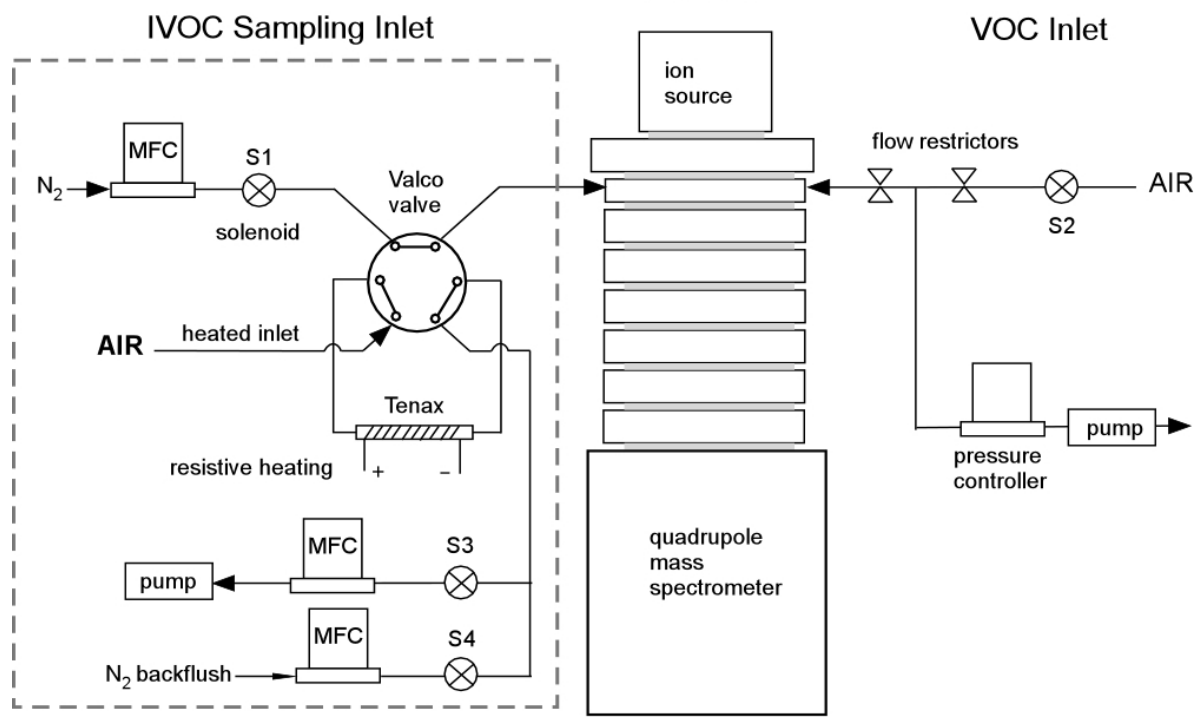

Fig. 1. Plumbing schematic of thermal desorption sampler for PTR-MS.

M. H. Erickson et al.

Title Page

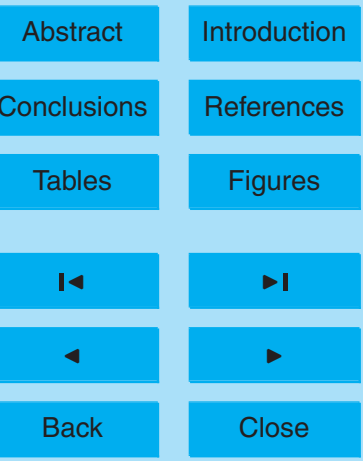

Full Screen / Esc

Printer-friendly Version

Interactive Discussion 


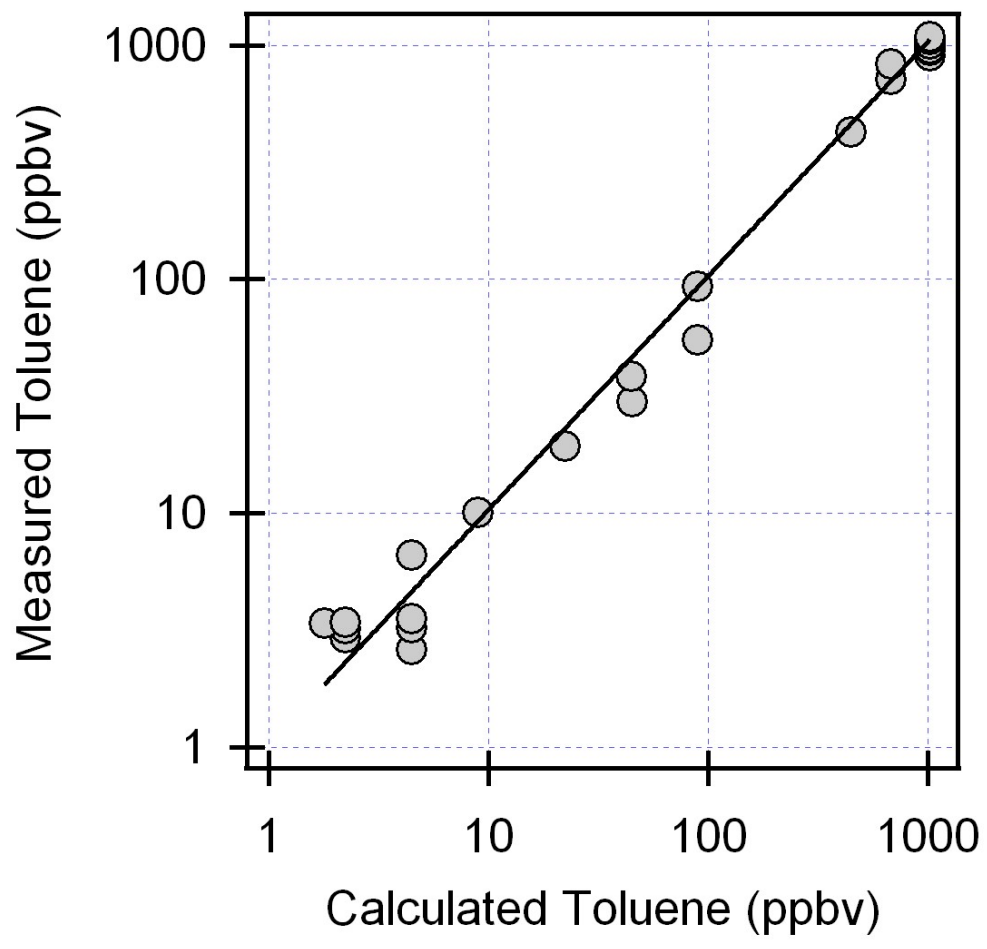

Fig. 2. Calibration of toluene test mixtures prepared with the dynamic dilution system. Line through points is a linear regression forced through zero with slope of $1.04 \pm 0.03$.

\section{ACPD}

$12,5389-5423,2012$

\section{Quantification of diesel exhaust gas phase organics}

M. H. Erickson et al.

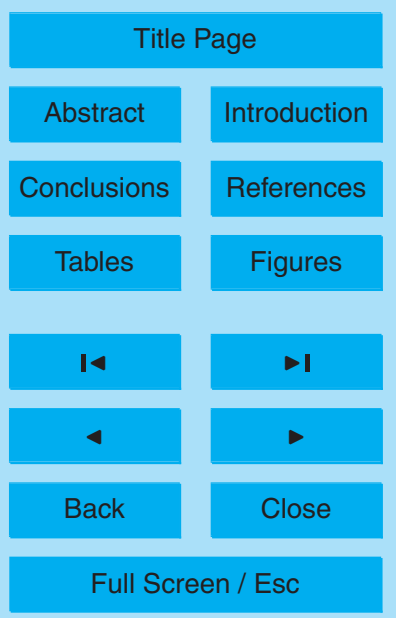

Printer-friendly Version

Interactive Discussion 


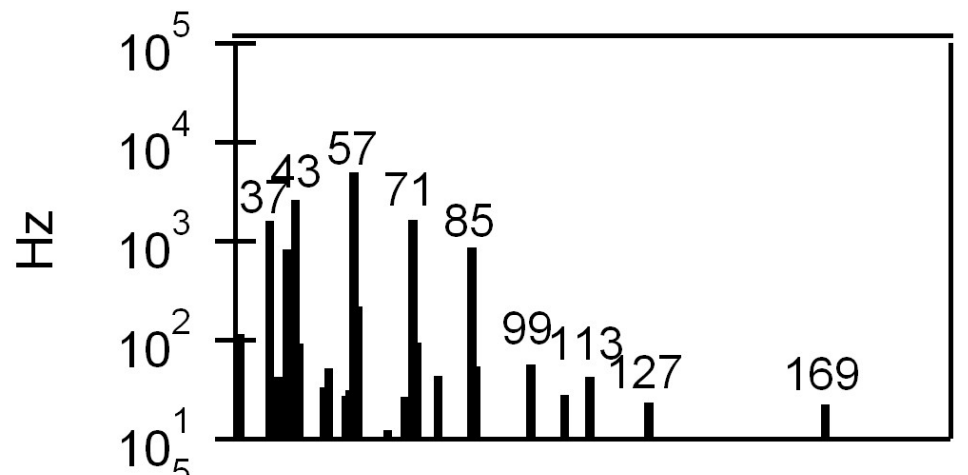

\section{ACPD}

12, 5389-5423, 2012

Quantification of diesel exhaust gas phase organics

M. H. Erickson et al.

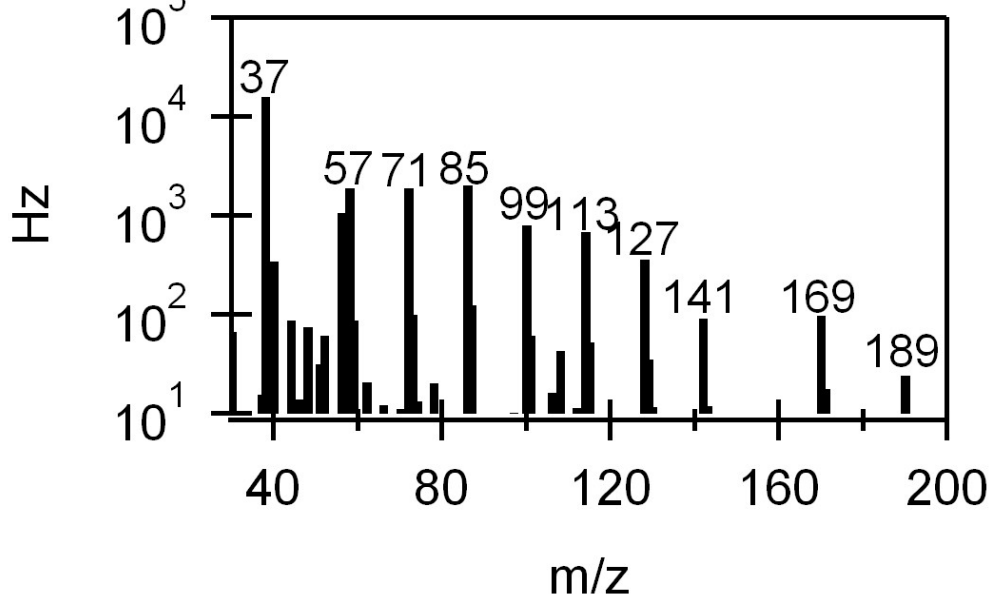

Title Page

Abstract

Introduction

Conclusions

References

Tables

Figures

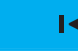

4

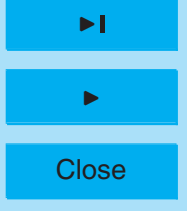

Back

Close

Full Screen / Esc

Printer-friendly Version

Fig. 3. PTR-MS mass spectrum of dodecane at $120 \mathrm{Td}$ (upper panel) and $80 \mathrm{Td}$ (lower panel) drift tube conditions.

Interactive Discussion 


\section{ACPD}

$12,5389-5423,2012$

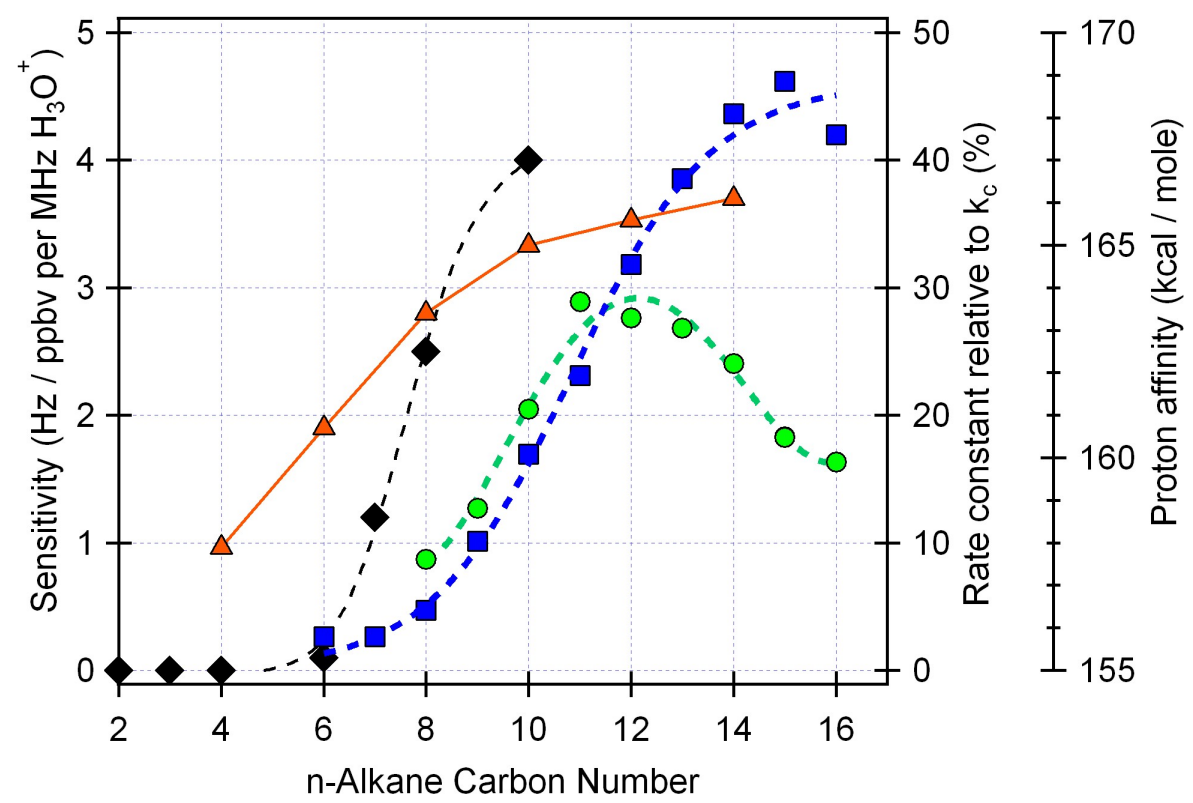

Fig. 4. Alkane sensitivity (left axis) for $120 \mathrm{Td}$ (blue squares) and $80 \mathrm{Td}$ (green circles) compared to measured $\mathrm{H}_{3} \mathrm{O}^{+}+$alkane rate coefficients (black diamonds) by Arnold et al. (1998) expressed as a percentage of collision rate limit (right axis). Also shown is the proton affinity (red triangles) determined by Hunter and East (2002).

\section{Quantification of diesel exhaust gas phase organics}

M. H. Erickson et al.

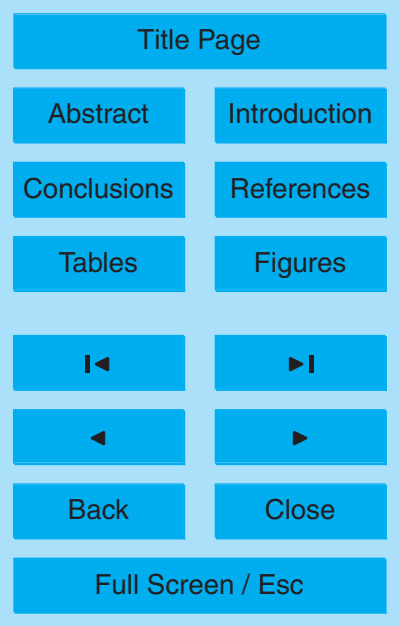

Printer-friendly Version

Interactive Discussion 

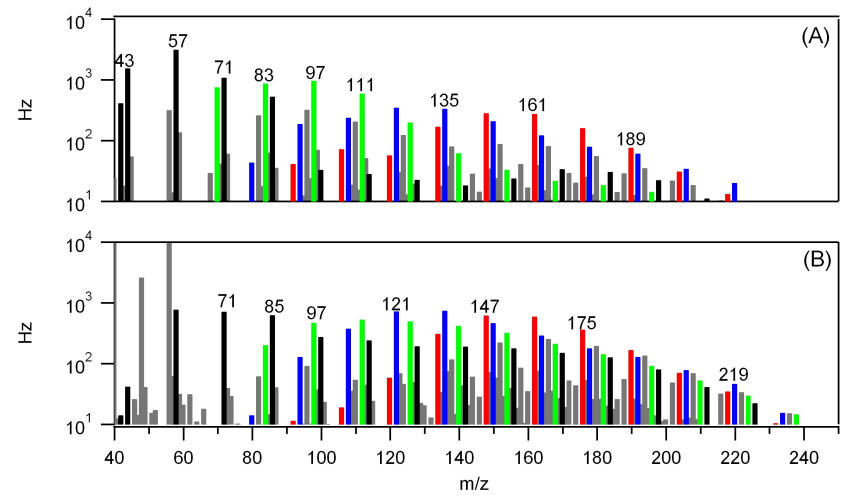

\section{ACPD}

12, 5389-5423, 2012

\section{Quantification of diesel exhaust gas phase organics}

M. H. Erickson et al.
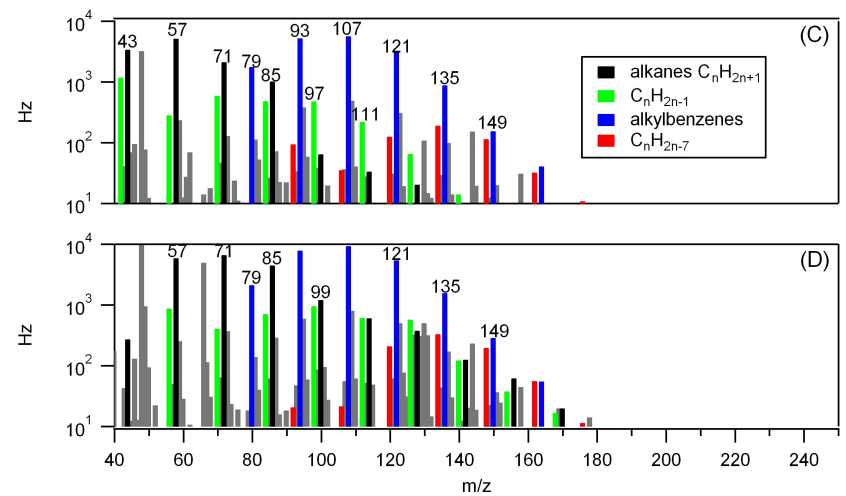

Fig. 5. Mass spectrum of \#2 diesel fuel at $120 \mathrm{Td}(\mathbf{A})$ and $80 \mathrm{Td}(\mathbf{B})$ and gasoline at $120 \mathrm{Td}$ (C) and $80 \mathrm{Td}$ (D). Ion signal has been color coded to assign ions to common fragmentation patterns that identify common organic compound classes. For diesel the ion signal is more evenly distributed across the 4 ion fragmentation groups than gasoline, while for the gasoline most of the ion signal was observed in the alkylbenzene group since the PTR-MS is insensitive to most of the light alkanes found in gasoline.

Title Page

Abstract

Conclusions Introduction

Tables References

Figures

14

4

Back

Close

\section{Full Screen / Esc}

Printer-friendly Version

Interactive Discussion 


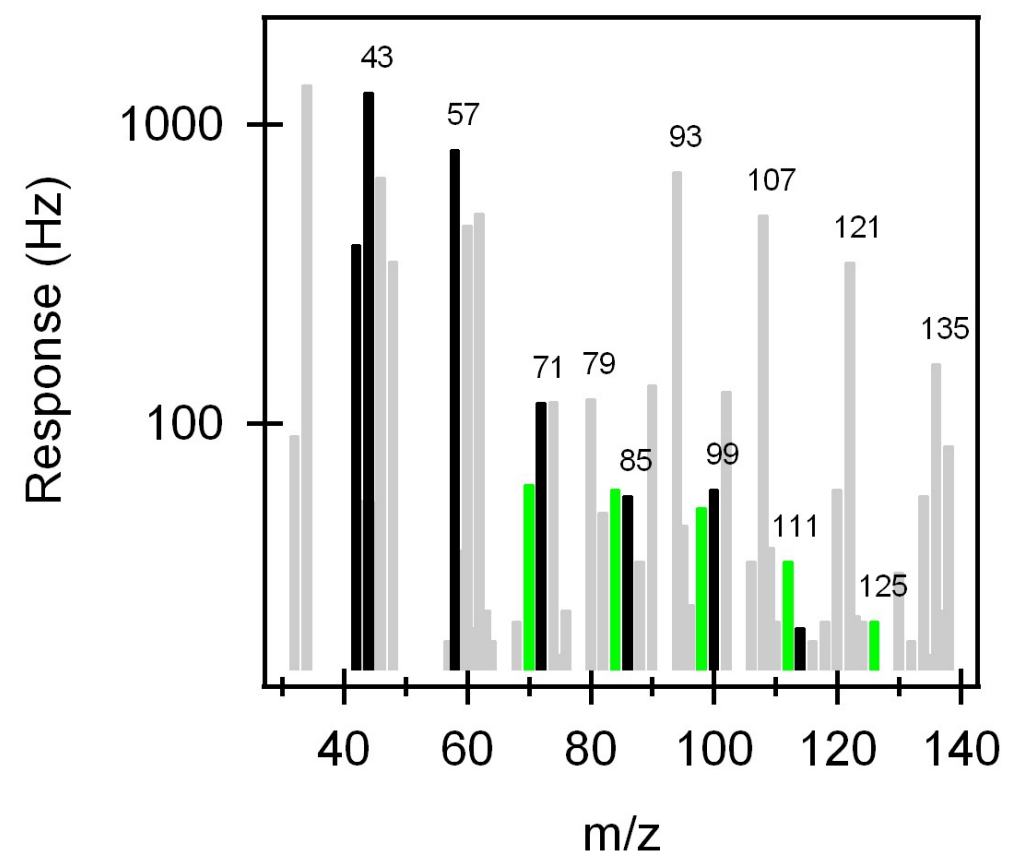

12, 5389-5423, 2012

Quantification of diesel exhaust gas phase organics

M. H. Erickson et al.

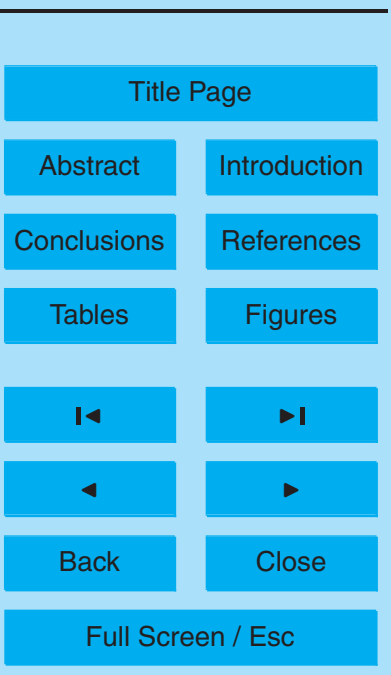

Fig. 6. Mass scan in Mexico City morning rush hour air on 8 March 2006. Black bars correspond to fragmentation ions observed from alkanes in diesel fuel $\left(m / z 41\right.$ and $\left.m / z C_{n} \mathrm{H}_{2 n+1}\right)$. Green bars correspond to ions observed in diesel fuel with formula $\mathrm{C}_{n} \mathrm{H}_{2 n-1}(m / z 69,83,97$, 111, 125). 


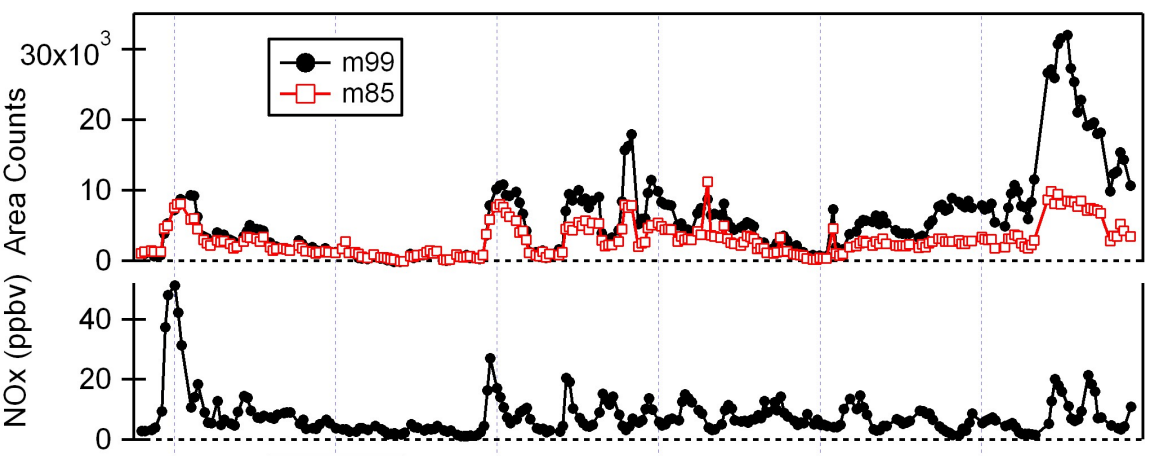

\section{ACPD}

12, 5389-5423, 2012

Quantification of diesel exhaust gas phase organics

M. H. Erickson et al.

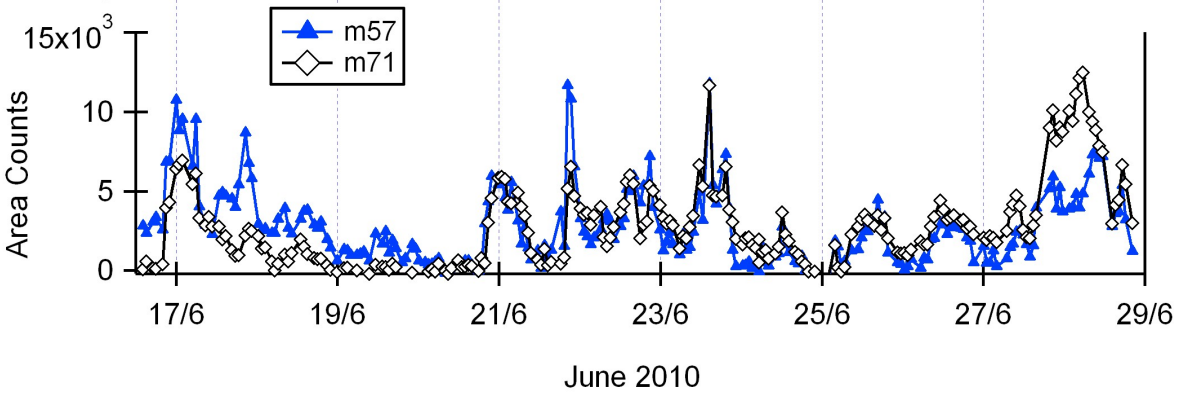

Abstract

Title Page

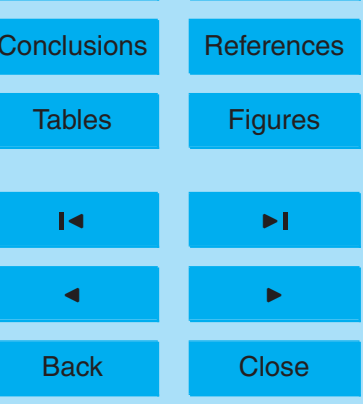

Full Screen / Esc

Fig. 7. Time series of $\mathrm{C}_{n} \mathrm{H}_{2 n+1}$ group ion response measured in IVOC mode during CARES. $\mathrm{NO}_{\mathrm{x}}$ mixing ratios averaged over the $30 \mathrm{~min}$ IVOC sampling period are also shown.

Printer-friendly Version

Interactive Discussion 


\section{ACPD}

$12,5389-5423,2012$
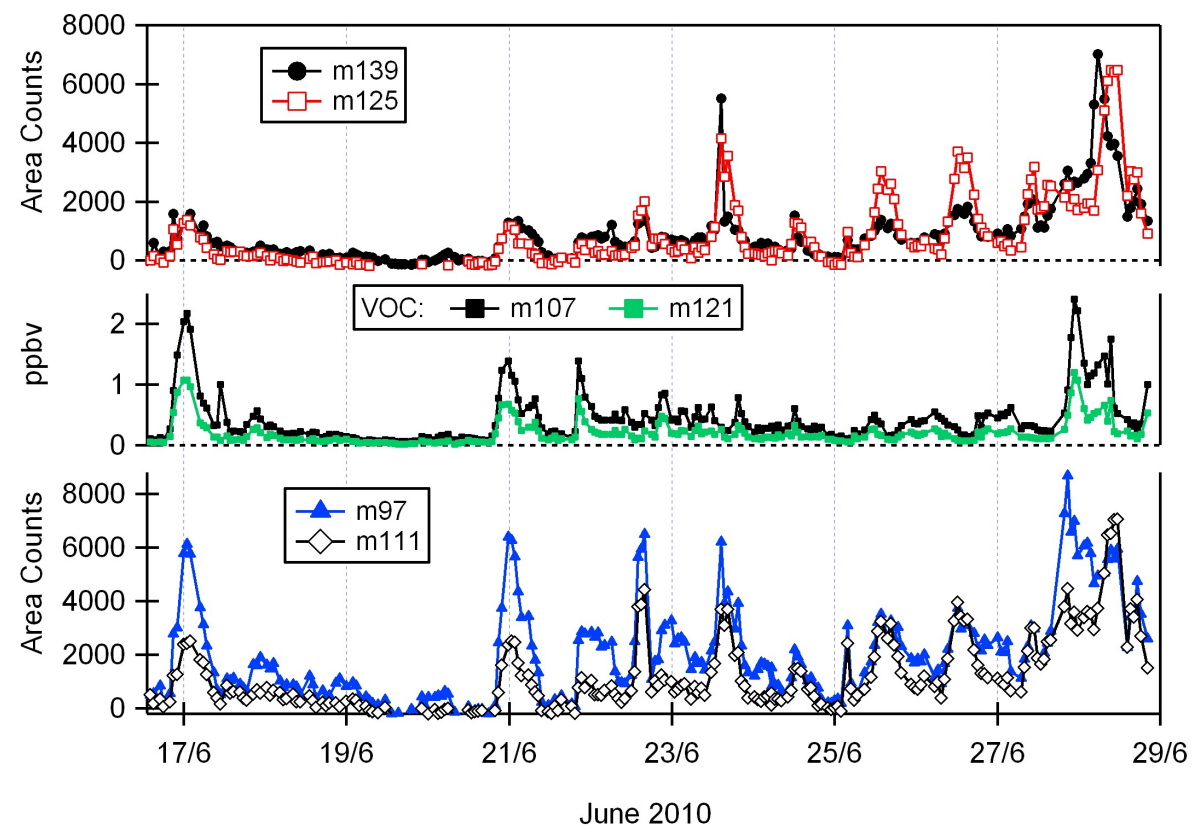

\section{Quantification of diesel exhaust gas phase organics}

M. H. Erickson et al.

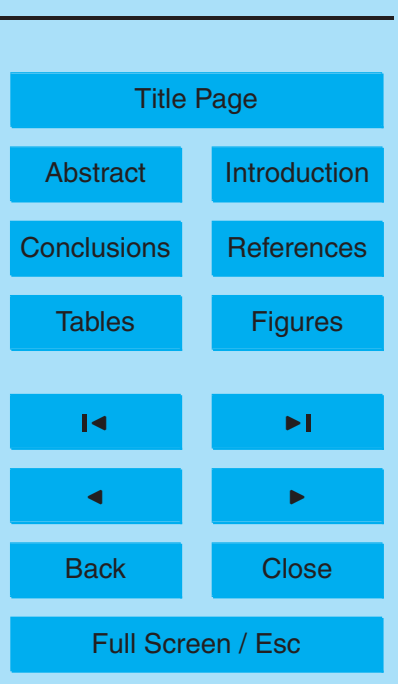

Fig. 8. Time series of $\mathrm{C}_{n} \mathrm{H}_{2 n-1}$ group ion response measured in IVOC mode during CARES. Shown in the middle panel are mixing ratios of $\mathrm{C}_{2}$-alkylbenzenes $(\mathrm{m} / \mathrm{z} 107)$ and $\mathrm{C}_{3}$ alkylbenzenes $(m / z 121)$ measured in VOC mode.

Printer-friendly Version

Interactive Discussion 


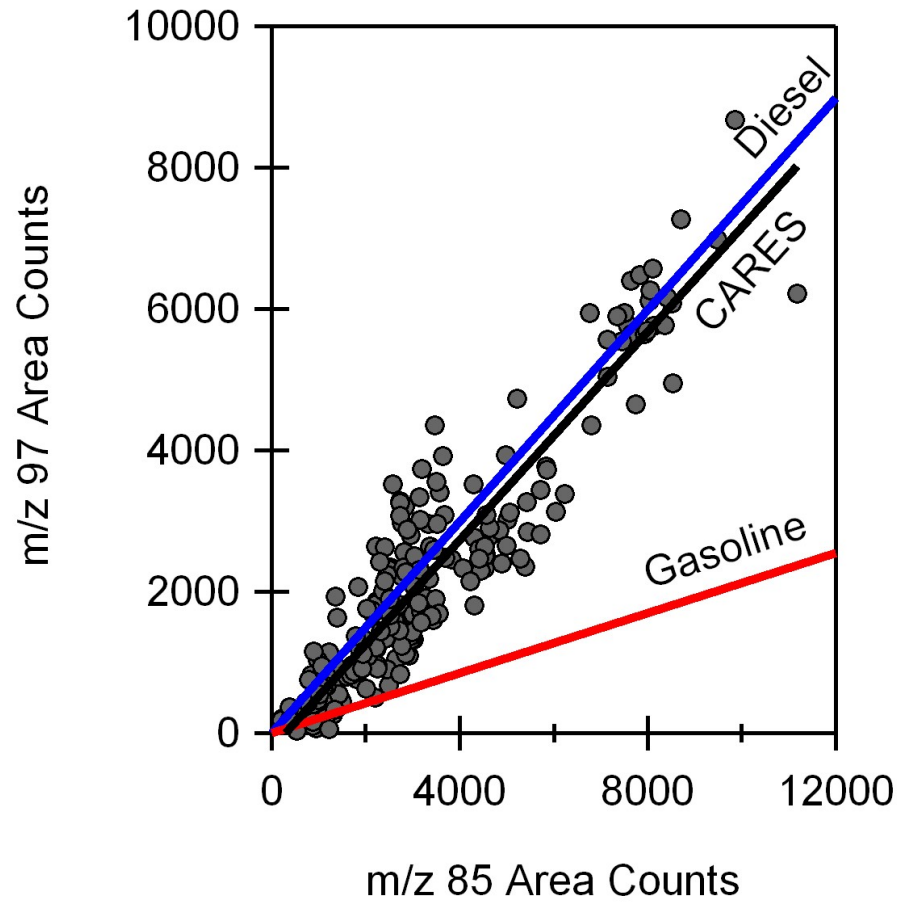

Fig. 9. Correlation between $\mathrm{m} / \mathrm{z} 97$ and $\mathrm{m} / \mathrm{z} 85$ during CARES. The diesel and gasoline reference lines are the $m / z 97$ to 85 ratios found from the fuel spectra displayed in Fig. 5 . The CARES data yields an $\mathrm{m} / \mathrm{z} 97$ to 85 ion intensity ratio of 0.74 similar to that of diesel fuel of 0.75 . The gasoline ratio is 0.21 .

\section{ACPD}

$12,5389-5423,2012$

\section{Quantification of diesel exhaust gas phase organics}

M. H. Erickson et al.

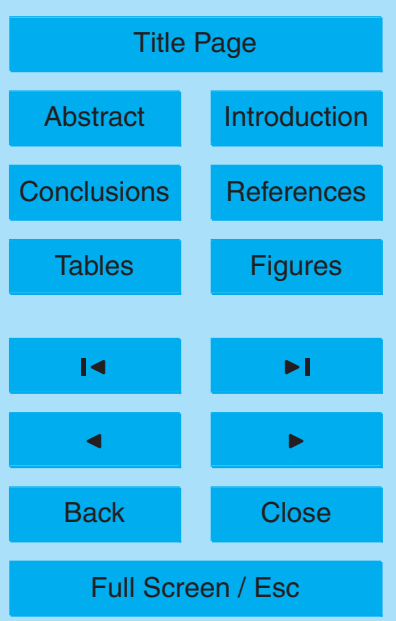

Printer-friendly Version

Interactive Discussion 


\section{ACPD}

12, 5389-5423, 2012

\section{Quantification of diesel exhaust gas phase organics}
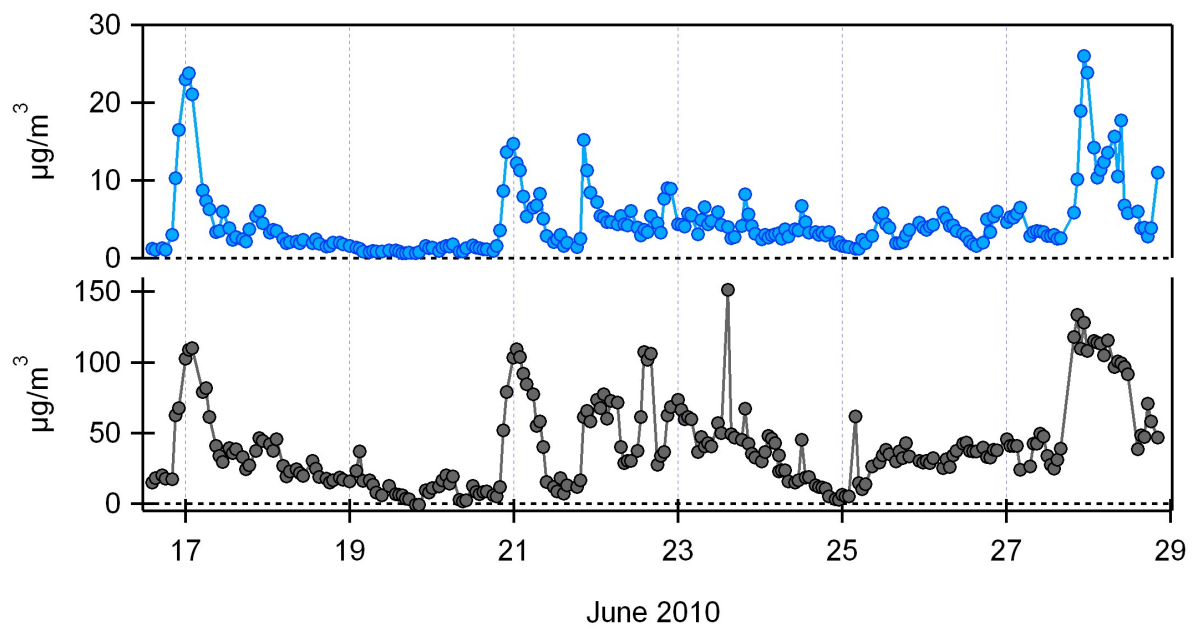

M. H. Erickson et al.

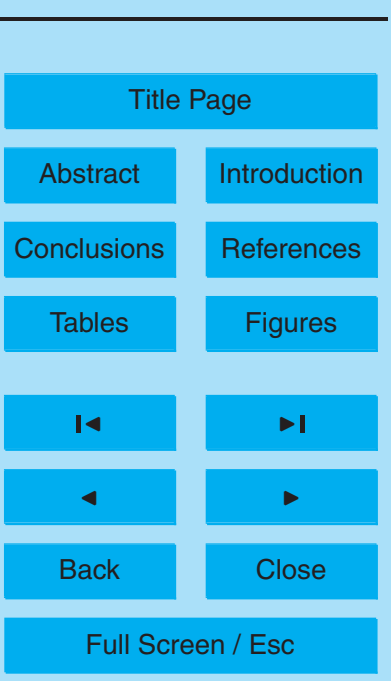

Printer-friendly Version

Interactive Discussion 


\section{ACPD}

$12,5389-5423,2012$
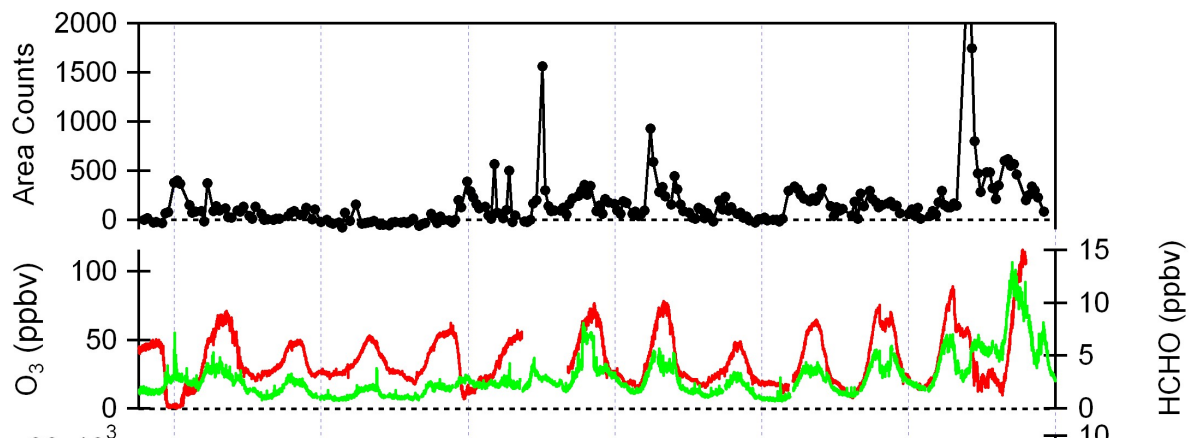

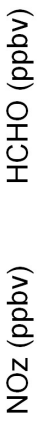

Quantification of diesel exhaust gas phase organics

M. H. Erickson et al.

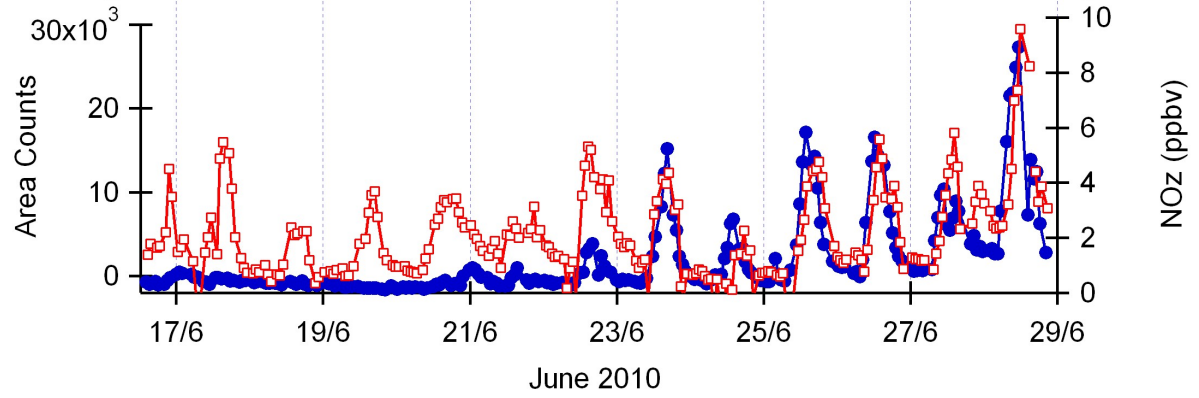

Fig. 11. Time series of $m / z 161$ area counts (upper panel), ozone (red trace) and formaldehyde (green trace) mixing ratios are shown in the middle panel, $\mathrm{m} / \mathrm{z} 143$ area counts (blue circles) and $\mathrm{NO}_{\mathrm{z}}$ (red squares) are shown in the lower panel.

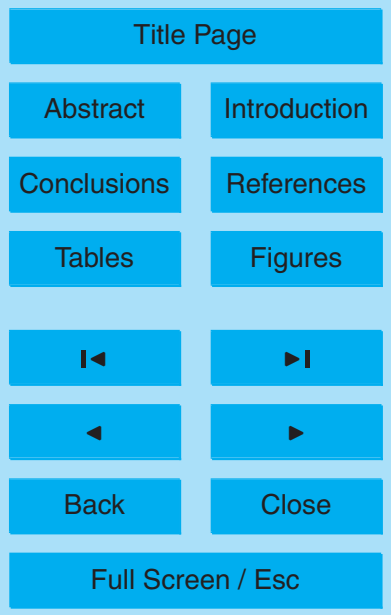

Printer-friendly Version

Interactive Discussion

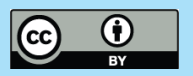

